IZA DP No. 4965

Labor Market Entry Conditions, Wages and Job Mobility

Ronald Bachmann

Thomas K. Bauer

Peggy David

May 2010 


\title{
Labor Market Entry Conditions, Wages and Job Mobility
}

\author{
Ronald Bachmann \\ RWI Essen
}

Thomas K. Bauer

RWI Essen, Ruhr-University Bochum

and IZA

\section{Peggy David}

Ruhr Graduate School in Economics

and RWI Essen

\author{
Discussion Paper No. 4965 \\ May 2010
}

\section{IZA}

P.O. Box 7240

53072 Bonn

Germany

Phone: +49-228-3894-0

Fax: +49-228-3894-180

E-mail: iza@iza.org

Any opinions expressed here are those of the author(s) and not those of IZA. Research published in this series may include views on policy, but the institute itself takes no institutional policy positions.

The Institute for the Study of Labor (IZA) in Bonn is a local and virtual international research center and a place of communication between science, politics and business. IZA is an independent nonprofit organization supported by Deutsche Post Foundation. The center is associated with the University of Bonn and offers a stimulating research environment through its international network, workshops and conferences, data service, project support, research visits and doctoral program. IZA engages in (i) original and internationally competitive research in all fields of labor economics, (ii) development of policy concepts, and (iii) dissemination of research results and concepts to the interested public.

IZA Discussion Papers often represent preliminary work and are circulated to encourage discussion. Citation of such a paper should account for its provisional character. A revised version may be available directly from the author. 


\section{ABSTRACT \\ Labor Market Entry Conditions, Wages and Job Mobility ${ }^{*}$}

Economic conditions at the time of labour market entry can induce wage differentials between workers entering the labour market at different points in time. While the existence and persistence of these entry wage differentials are well documented, little is known about their interaction with employees' mobility behaviour. This paper contributes to this research area by analyzing the interaction between job mobility and entry wage differentials using German administrative data. The results suggest that labour market entrants earning less than the average starting wage are more likely to change jobs, directly from employer to employer as well as indirectly via an unemployment spell. In addition they are more likely to change occupation. Moreover, job mobility tends to reduce the effects of labour market entry conditions, implying that job mobility operates as an adjustment mechanism that mitigates entry wage differentials. These results hold not only for high-skilled, but also for mediumskilled and unskilled workers.

JEL Classification: E24, J31, J62, J64

Keywords: mobility, job-to-job, wages, labour market entry, initial conditions

Corresponding author:

Peggy David

RWI

Hohenzollernstr. 1-3

45128 Essen

Germany

E-mail: david@rwi-essen.de

\footnotetext{
* We are grateful to Dirk Antonczyk, Colin Green, Michael Kvasnicka, Jörn-Steffen Pischke, Andrea Weber and Thomas Zwick, as well as to participants at the 12th IZA Summer School, the EALE 2009 Annual Conference, the ESPE 2009 Annual Congress, the Scottish Economic Society 2009 Annual Meeting, the 15th Conference on Panel Data, the COST workshop (Wages and Firms), the DFG-SPP March 2009 workshop, the Leibniz Seminar of BENA, the Jena Economic Research Seminar, and seminars at RWI for helpful comments. We also thank the staff of the Research Data Centre of the IAB for their help with the data. Part of this research was carried out while Peggy David visited the Department of Economics at Columbia University and Humboldt-Universität zu Berlin, which she thanks for their hospitality. Financial support from the German Science Foundation (DFG) through SPP 1169 "Flexibility in Heterogeneous Labor Markets" and from the Leibniz Association is gratefully acknowledged.
} 


\section{Introduction}

A number of empirical studies suggests that prevailing economic conditions at the time workers enter the labour market significantly affect their earnings (e.g. Bloom and Freeman, 1986, and Shin, 1994). Whether these wage effects are persistent has been a widely studied question, yielding ambiguous results (e.g. Baker, Gibbs, and Holmstrom, 1994, Oreopoulos, von Wachter, and Heisz, 2008, Harris and Holmstrom, 1982, Welch, 1979). The standard competitive model implies that the labour market operates as a spot market, where wages are solely determined by labour demand and labour supply and thus are equal to the individual's marginal productivity. In such a model, labour market shocks at the beginning of a worker's career - arising, for example, from variations in the cohort size or business cycle fluctuations - are temporary and do not lead to long-lasting wage effects. Alternative economic theories, such as, for example, models of implicit contracts, suggest, however, that differences in initial labour market conditions can induce persistent wage differentials between entry cohorts (e.g. Harris and Holmstrom, 1982).

Compared to the large body of theoretical and empirical studies on the existence and persistence of the effects of initial labour market conditions on wages, research on how conditions at the time of labour market entry are related to workers' job mobility remains scarce. Looking at a sample of Canadian college graduates, Oreopoulos, von Wachter, and Heisz (2008) provide one of the few studies analyzing the impact of job-starting conditions on worker's early career. They document that the unemployment rate at job entry, diminishing the worker's starting wage, significantly raises the probability of job separation. Furthermore, they provide descriptive evidence that this increased job mobility in turn positively affects wages, and therefore is able to partly reverse the earnings losses experienced through less favourable career starting conditions. In a related vein, we study the relationship between economic starting conditions and early job mobility addressing two questions: (i) Do wage differentials induced by initial conditions significantly affect an individual's mobility decision, and (ii) does job mobility act as adjustment mechanism in such a way as to reduce these initial wage gaps?

In order to answer these questions, we employ a large administrative data set representing $2 \%$ of German employees. Our analysis proceeds in three steps. First, we quantify the impact of economic conditions on the wages of labour market entrants. Second, we examine the determinants of 
individual job mobility, emphasizing the effect of entry conditions. Finally, using an instrumental variable approach we analyse to what extent worker mobility contributes to the mitigation of entry wage differentials between different cohorts. In contrast to previous studies that analyze the different potential causes of initial conditions, we concentrate on a more general approach and focus on pure year effects acting as a proxy for the effects of entry conditions.

The following analysis contributes to the existing literature in several ways. First, we are able to distinguish between various destination states, between voluntary and involuntary job mobility, and between job mobility with and without a change of occupation. This allows us to provide a very detailed picture of the effects of initial wage differentials on different types of job mobility and of the potential of these different types of job mobility to mitigate existing wage differentials arising through different economic conditions at the time of labour market entry. Second, using an instrumental variable approach, we are able to identify the causal impact of these different types of job mobility on entry wage differentials. Finally, differently to other empirical studies in this area, which often concentrate on single sectors or skill levels (see e.g. Oreopoulos, von Wachter, and Heisz (2008), who concentrate on college graduates), we use a large and representative sample of labour market entrants in West Germany. This allows us to consider all sectors of the economy, and to provide a detailed analysis for different skill levels.

The empirical results suggest that wage differentials induced by labour market entry conditions play an important role in explaining job transitions. Workers entering the labour market under unfavourable conditions and earning less than the average starting wage show an increased mobility compared to workers entering during more favourable times and earning average or higher-than-average starting wages. Moreover, the wage discrepancies that occur between workers entering the labour market at different points in time decrease with experience. Direct and indirect labour market transitions further reduce initial wage gaps, implying that job mobility operates as an adjustment mechanism. These results hold for all skill groups and types of job mobility considered in the analysis.

The remainder of this paper is organized as follows. The next section contains a review of the literature on initial conditions, cohort effects, and early job mobility. Section 3 presents a description of the data set, particularly addressing the identification of job transitions. In Section 4 the methodology used in this paper is discussed. Descriptive statistics and 
estimation results as well as several sensitivity analyses are presented in Section 5. Section 6 concludes.

\section{Initial Conditions, Cohort Effects and Job Mobility}

The analysis conducted in this paper builds on two strands of the literature: (i) studies on the impact of initial labour market conditions on earnings, and (ii) the job mobility literature, analyzing the determinants and wage effects of individual job transitions. In this section, we provide a brief survey of the existing theoretical and empirical studies for both strands. Although the subsequent empirical analysis does not concentrate on the different potential sources of entry wage differentials, our overview also covers studies providing various explanations for differences in wages between entry cohorts.

\subsection{Initial Labour Market Conditions and Wages}

The economic literature provides several arguments why initial labour market conditions might lead to wage differentials between entry cohorts. Studies examining the impact of the demographic cycle on earnings find that a considerable increase in labour supply - emanating, for example, from the entry of baby boomers into the job market - adversely affects entry wages (Freeman, 1979, and Welch, 1979). The analysis whether these wage disadvantages remain throughout workers' careers has created contention among researchers (Berger, 1989, Bloom, Freeman, and Korenman, 1987, and Murphy, Plant, and Welch, 1988). Bloom, Freeman, and Korenman (1987) track the progress of different U.S. cohorts from 1969 to 1984. Their results suggest that large cohorts are able to at least partly catch up in earnings within a decade after labour market entry. Welch (1979) finds similar results for the period from 1967 to 1975 and confirms that wage disadvantages do not persist as the cohort ages. Berger (1989), however, using almost identical data but less restrictive assumptions does not find any convergence in wages across cohorts.

Wage differentials between entry cohorts may also be the result of labour demand shocks, such as technological progress or business cycle fluctuations. Existing evidence suggests that individuals hired during economic recessions experience lower entry wages than individuals hired in economic upturns (e.g. Bils, 1985, Solon, Barsky, and Parker, 1994, and Martins, Solon, and Thomas, 2010). Furthermore, several studies indicate that this 
cohort effect is persistent (e.g. Oreopoulos, von Wachter, and Heisz, 2008, Oyer, 2006, and von Wachter and Bender, 2008). Several theories can be put forward to explain this long-term impact of poor initial economic conditions. Models of implicit contracts, developed for example by Azariadis (1975) as well as Harris and Holmstrom (1982) and empirically tested by Beaudry and DiNardo (1991), and Baker, Gibbs, and Holmstrom (1994), suggest that business cycle conditions at the time of labour market entry may affect individuals' long-term wages, because of missing or insufficient wage adjustments. Another type of model focuses on cyclical variations in hiring and promotion standards, which might lead to differences in workers' productivity, and hence to differences in current and future earnings (Okun, 1973, and Reder, 1955). A prevalent explanation for persistent cohort effects is based on the human capital model, stating that the initial economic situation affects workers' opportunity to accumulate skills and thus has a sustained impact on individual labour market performance (Gibbons and Waldman, 2004).

\subsection{Early Job Mobility}

Workers' careers - and in particular young workers' careers - can be characterized by a two-sided search process: Workers search for firms that value their skills most highly, while firms search for the most productive workers (Jovanovic, 1979). Labour market entrants may not be able to immediately find an employer that offers them the most productive jobs, which implies that job transitions are an integral part of early working lives (Topel and Ward, 1992). Thus early job mobility plays an important role in improving the quality of job matches and hence for the evolution of workers' wages. This especially holds true in times of unfavourable economic conditions, when suitable jobs are particularly hard to find. Note, however, that job transitions as a mechanism to adjust workers' early wages to average market wages are not taken into account by the theories of cohort wage effects mentioned above.

Empirical studies examining the determinants of job transitions early in the career suggest that the wage level is crucial for individual mobility. Topel and Ward (1992), for example, analyze the mobility patterns of young men and find a lower job stability for lower-paid jobs. This corresponds to results reported by Oreopoulos, von Wachter, and Heisz (2008), who show that economic downturns, diminishing workers starting wage, significantly raise the rate of job change. Common explanations for these 
findings are based on job search (Burdett, 1979) and job matching approaches (Jovanovic, 1979), which predict a long-lasting catch-up process if wages have temporarily declined. Thus, workers who do not experience sustained productivity increases tend to search for better jobs that offer higher wages and higher match qualities. This implies that employer-toemployer transitions that occur for voluntary reasons are able to increase young workers' wages.

Empirical evidence confirms the beneficial wage effects of voluntary job mobility which takes place during the early stages of peoples' working lives. Antel (1986), and Bartel and Borjas (1978), for example, find mobility-induced wage premiums that range between $8 \%$ and $20 \%$. Similarly, the analysis by Oreopoulos, von Wachter, and Heisz (2008) indicates that wage disadvantages, experienced by workers graduating in a recession, are partly reversed through job changes. This implies that individuals affected by poor initial labour market conditions might use the opportunity to advance in their careers through job changes, avoiding persistent earnings disadvantages and yielding a convergence between cohort and average market wages.

Likewise, firms may eventually lay off workers who experience relatively high wages because of favourable starting conditions. This kind of separation might lead to a loss of initial wage advantages and therefore also contributes to a reduction of entry wage differentials. A prevalent explanation for wage losses of displaced workers is based on human capital theory (Becker, 1975). It suggests that investments in job-specific skills create a higher earnings potential, making job mobility less profitable. Gibbons and Katz (1991) argue that at the time of hiring, employers are insufficiently informed about workers' productivity. Since firms have an incentive to lay off less able workers, displacements may serve as a negative signal to other employers. This adverse selection of job movers implies that involuntary employer-to-employer transitions may entail negative wage effects, which has been confirmed by several empirical studies. Kletzer and Fairlie (2003) and von Wachter and Bender (2006), for example, point to the fact that job displacements in workers' early careers lead to sizeable and persistent wage losses. Similarly, von Wachter and Bender (2008) show that initial wage advantages, obtained from favourable labour market conditions, are reduced when workers lose their job. There are only very few papers (e.g. Antel, 1986, and Perez and Sanz, 2005) which analyze voluntary and involuntary job changes simultaneously and thus allow for both beneficial as well as unfavourable mobility. 


\section{Data}

In the following analysis we employ the IAB Employment Sample (IABS), a data set provided by the Institute for Employment Research (IAB). The IABS is a $2 \%$ representative sample of the Employment Statistics Register, an administrative panel data set of the employment history of all individuals in Germany who worked between 1975 and 2004 in an employment relationship covered by social security, supplemented with information on all unemployment spells of the workers covered. For 1995, the Employment Statistics Register contains the labour market history of $79.4 \%$ of all employed persons in Western Germany, and $86.2 \%$ of all employed persons in Eastern Germany. ${ }^{1}$

The data set provides information on gross daily wages subject to social security contributions, which we deflate using consumer prices (base year 2000). Further worker characteristics included are the employees' year of birth, sex, nationality, and education. To meet the problem of inconsistent and missing information on the individual's education, we corrected the education variable following an imputation procedure provided by Fitzenberger, Osikumino, and Völter (2006). ${ }^{2}$

The sample is restricted to West-German individuals who started their career between 1980 and 1999, because the record on unemployment benefit recipients are unreliably measured before 1980. We analyze the career paths of these individuals in their first five years on the labour market. For a better comparison of wages, part-time workers, homeworkers, trainees, and individuals with parallel employment spells have been excluded from the analysis. For each entry cohort we trim wages at the 1st and 99th percentiles and leave unconsidered starting wages close to the contribution ceiling. ${ }^{3}$ Finally, we drop individuals with missing values for the variables

\footnotetext{
${ }^{1}$ The employee history is based on the integrated notification procedure for health insurance, the statutory pension scheme, and unemployment insurance. At the beginning and at the end of any employment spell, employers are required to notify the social security agencies. This information is exact to the day. For spells spanning more than one calendar year, an annual report for each employee registered within the social insurance system is compulsory, and provides an update on, for example, the qualification and the current occupation of the employee. Civil servants and self-employed workers are not included in the data. A detailed description of the Employment Statistics Register and the notification procedure is given by Bender, Haas, and Klose (2000).

${ }^{2}$ Particularly, we use the imputation procedure 2B by Fitzenberger, Osikumino, and Völter (2006), where education reports are extrapolated if a person's education sequence is consistent, i.e. non-decreasing over time.

${ }^{3}$ Other studies based on administrative individual data are usually subject to the problem that the wage information in the IABS is censored at the social contribution ceiling. Because we only consider individuals entering the labour market for the first time, these data problems barely affect our analysis: Less than $0.4 \%$ of the workers' starting wages are top coded. Within
} 
used in the empirical analysis. Applying these selection criteria, our final sample comprises 195,384 labour market entrants with a total of about 1.3 million spells.

The IABS is representative regarding employment covered by the social security system but not regarding unemployment, because only those unemployed who are entitled to transfer payments are covered. ${ }^{4}$ The available information allows to derive three labour market states at each moment in time: employment covered by social security (E), unemployment (U), if the worker is receiving transfer payments, and non-participation (N). Since the latter state cannot be directly observed, we define non-participants as individuals leaving the sample. Therefore, transitions to non-participation include also transitions to the civil service, to self-employment, retirement or marginal employment, because these destinations are not covered by social security legislation and are therefore not covered by the Employment Statistics Register.

Since the IABS data set contains daily information on the employment and unemployment history of every individual in the sample, it is possible to calculate separation flows taking into account every change of the labour market state that occurs within a certain time period. Using the establishment identification number provided in the data set, we are able to identify three different separation flows: transitions (i) from employment to nonparticipation (EN), (ii) from employment to unemployment (EU) and (iii) from employment to another employment relationship (EE). As firms and workers may fail to correctly report the beginning and the end of a job or of a period of unemployment, we disregard small gaps in the records. In particular, we define a direct transition between two labour market states if the time lag between two spells (employment or unemployment) is smaller than 30 days. It should be noted that our definition of a job is based on the establishment level rather than on the firm level. Hence, transitions from one establishment to another one within the same firm are treated as employer-to-employer flow.

Concerning EE flows, research has pointed out that a distinction between voluntary and involuntary job changes proves to be important (Antel,

the first five years of labour market experience about $3 \%$ of the workers reach wages affected by the contribution ceiling.

${ }^{4}$ For example, workers who fail to report to the unemployment office are not counted as unemployed even if they have been laid off and are looking for a job. The same is true for workers who, during the two years prior to unemployment, have worked for less than 12 months in a job covered by social security legislation. Also, workers can be temporarily denied unemployment benefits for different reasons (e.g. unjustified job quits, failure to take up an acceptable job), and are not recorded as unemployed for periods of non-receipt of benefits. 
1986). Since the IABS data do not designate any reason for a job separation, we are not able to directly differentiate between voluntary and involuntary moves. As an alternative, we follow previous studies (e.g. Perez and Sanz, 2005) and compare direct employer-to-employer transitions and those with an intervening unemployment spell of less than 1 month $\left(E E^{D}\right)$ to employer-to-employer transitions with an intervening unemployment spell that is larger than 1 month $\left(E E^{I D}\right) .{ }^{5}$ Corresponding to the notion in the job mobility literature, the first type of separation is most likely initiated by the worker and therefore interpreted as a voluntary move. The latter one, however, results most likely from a lay-off and is considered to be an involuntary move. ${ }^{6}$ Transition rates are calculated by using aggregate employment as denominator.

\section{Econometric Framework}

\subsection{Job Mobility}

In the first part of the empirical analysis, we estimate the probability of experiencing different types of job transitions $E_{i e t}$ by using a standard probit model:

$$
\operatorname{Pr}\left(E_{\text {iet }}=1 \mid X, Z\right)=\Phi\left(\beta_{1} X_{i t}+\beta_{2} Z_{e t}+\beta_{3} T_{t}+\gamma_{1} C_{i}^{A}+\gamma_{2} C_{i}^{B}\right),
$$

where $\Phi(\cdot)$ is the standard normal cumulative distribution function. In order to obtain a general idea of young workers' mobility behaviour, we analyze transitions from one employer to another (EE), from employment to unemployment (EU), and from employment to non-participation (EN). With respect to employer-to-employer transitions, we differentiate between direct employer changes $\left(\mathrm{EE}^{D}\right)$ and indirect employer changes $\left(\mathrm{EE}^{I D}\right)$ as described in the previous section. $X_{i t}$ is a vector of individual characteristics, including gender, skill level, and employment duration, and $Z_{e t}$ a vector of establishment characteristics, including establishment size and industry dummies. In order to account for differences in economic conditions

\footnotetext{
${ }^{5}$ Our data set only records unemployment spells if the worker receives unemployment benefits. We are thus not able to identify the true length of unemployment. Following Fitzenberger and Wilke (2006), we therefore use the nonemployment period as a proxy for the true unemployment period, which is defined as all nonemployment spells after an employment spell including at least one period with receipt of transfer benefits.

${ }^{6}$ Using this definition, job separations induced by the employer might be considered as voluntary moves. This is possible, for example, if the employer notifies the worker in advance that he will be laid off, giving him the opportunity to search on-the-job. We therefore view our measure of voluntary transitions as an upper bound.
} 
at the time of separation, we include year dummies $\left(T_{t}\right)$.

The explanatory variable of main interest is the wage effect of labour market conditions at the beginning of the worker's career $\left(C_{i}\right)$. In order to calculate these initial wage differentials, we estimate the following wage regression using OLS:

$$
\ln w_{i 0}=\alpha_{0}+\alpha_{1} X_{i 0}+\alpha_{2} Z_{e 0}+\sum_{j=2}^{J} \delta_{j} C_{j}+\epsilon_{i 0},
$$

where $\ln w_{i 0}$ refers to the real daily $\log$ wage of individual $i$ at the time of entering the labour market $(\mathrm{t}=0), X_{i 0}$ is a vector of individual characteristics, and $Z_{e 0}$ a vector of establishment characteristics. The vectors $\alpha_{0}, \alpha_{1}, \alpha_{2}$, and $\delta_{j}$ are parameters to be estimated. $C_{j}$ denotes a set of $j-1$ dummy variables indicating the year an individual enters the labour market. These variables constitute a summary measure of the conditions prevailing at the time of labour market entry which include, for example, business conditions and the size of the cohort entering the labour market in a given year. The coefficients $\delta_{j}$ obtained from estimating equation (2) by using an arbitrarily chosen reference year, are transformed into percentage deviations from the grand mean of starting wages following Jann (2005). Using these starting wage deviations, we constructed the two variables $C_{i}^{A}$ and $C_{i}^{B}$, comprising entry wages larger and smaller than the average entry wage across the period under study, respectively. Both variables enter equation (1) in absolute values. By using $C_{i}^{A}$ and $C_{i}^{B}$, we allow positive and negative deviations to have different effects on the transition probabilities. $^{7}$ Table A.1 provides definitions as well as summary statistics of all worker and establishment characteristics used in the empirical analysis.

\subsection{Development of Entry Wage Differentials}

In the second part of the empirical analysis, we investigate whether job mobility contributes to a decrease in the initial wage differential between labour market entrants across years within the first five years of their labour market career. The analysis concentrates on individuals who stayed in their first job and individuals who change employers either directly or indirectly. The effect of these different types of job mobility on entry wage differentials

\footnotetext{
${ }^{7}$ Since predicted variables are included as regressors, standard errors are corrected following Murphy and Topel (1985).
} 
is analyzed by estimating the following model:

$$
\begin{aligned}
\ln w_{i 5}= & \gamma_{1}+\gamma_{2} X_{i 5}+\gamma_{3} Z_{e 5}+\gamma_{4} E E_{i 5}^{D}+\gamma_{5} E E_{i 5}^{I D}+\sum_{j=2}^{J} \delta_{j} C_{j} \\
& +\sum_{j=2}^{J} \theta_{1 j} C_{j} E E_{i 5}^{D}+\sum_{j=2}^{J} \theta_{2 j} C_{j} E E_{i 5}^{I D}+\epsilon_{i 5} .
\end{aligned}
$$

Unlike in model (2), we now examine the workers' wages five years after their labour market entry $(t=5)$. Moreover, equation (3) extends model (2) by including two dummy variables $E E_{i 5}^{D}$ and $E E_{i 5}^{I D}$, which indicate whether only direct or only indirect employer changes took place in the first five years of labour market experience. In order to gauge the wage effect of mobility for workers entering the labour market in different years, we interact these two indicator variables with the entry year dummies $C_{j}$.

The failure to control for the simultaneous determination of wages and mobility may result in biased and inconsistent estimators (Abowd, Kramarz, and Roux, 2006, Altonji and Shakotko, 1987, and von Wachter and Bender, 2006). We address the possible endogeneity of changing employers by using an instrumental variable approach. We exploit the idea that workers are pulled into new jobs due to improved outside job opportunities, while they are pushed out of their current job because of worsened economic conditions (McLaughlin, 1991). In order to do so, we use the annual industry employment growth rate as an instrument for the probability of voluntary mobility, arguing that more job openings are available in growing industries, which positively affects the likelihood of a voluntary job change, and that workers are more likely to change jobs within the same industry due to industry-specific human capital. ${ }^{8}$ Following Goeggel and Zwick (2009), who analyze the job and wage mobility behaviour of German apprentices, we further use a mass- layoff indicator as an instrument for the probability of involuntary job mobility. Using the establishment size reported in the IABS data set, we define mass layoffs as an annual reduction of the establishment's labour force by more than 30 percent. It is assumed that workers are more likely to leave the job involuntarily if the employment in their establishment was reduced significantly in the year of separation. It seems plausible to argue that both instruments are uncorrelated to unobservable individual characteristics affecting wages. Furthermore, as shown in Section 5.4, the industry employment growh rate as well as the

\footnotetext{
${ }^{8}$ Growth rates are calculated by using official figures on industry-specific employment provided by the German Statistical Office.
} 
mass-layoff indicator are highly correlated with the workers' likelihood to change employers directly and indirectly, respectively, making them strong instruments.

\section{Empirical Results}

\subsection{Entry Wage Differentials}

Before we turn to the impact of initial labour market conditions on workers' mobility behaviour and the role of job mobility in adjusting wage differentials, we show the pattern of initial wage gaps as well as the evolution of wages over time for workers entering the labour market in different years. Figure 1 plots the development of average log real daily wages for the cohorts starting their career between 1980 and 1999. It additionally shows the workers' average wages at the time of labour market entry as well as five years later. The figure reveals that average starting wages vary significantly across workers entering the labor market in different years. However, the observed entry wage differentials appear to decrease slowly over time.

As mentioned in Section 2, cohort wage effects at the time of labour market entry might be the result of labour demand shocks. The relation between this type of shock and average entry wages is shown in Figure 2, which compares detrended average starting wages with variations in the business cycle. It is evident that wages at the time of labour market entry follow the GDP growth rate. A simple correlation analysis shows that the correlation between entry wages and the GDP growth rate rises from 0.01 when using the contemporary GDP growth rate to a maximum of 0.50 when using the GDP growth rate lagged by two years.

The observed variations in starting wages may not solely be driven by differences in labour market entry conditions, but also by variations in the composition of the worker groups entering the labour market in different years. The corresponding summary statistics, which are reported in Table A.2, show that workers entering in different years only differ slightly in observable characteristics (share of females, share of skill groups and cohort size). This issue is examined explicitly in Table 1, which presents the entry year effects obtained by estimating several specifications of equation (2). With the exception of workers entering the labour market in 1990, worker groups entering in all years earn starting wages that significantly differ from the average entry wage in the period under study. For example, workers starting their working career in 1980 earn $21.4 \%$ less than the aver- 
age, while entrants in 1999 have starting wages $21.3 \%$ above the average. ${ }^{9}$ Taking into account observable individual (skill level, gender) and establishment characteristics (industry, region, establishment size) reduces the estimated year effects (see column (2) of Table 1). Column (3) of Table 1 shows that the wage differentials between entry cohorts are further reduced when we control for a linear time trend in addition to composition effects. Despite these additional controls, however, entry wage differentials remain statistically significant ranging from $-11 \%$ in the year 1984 to almost $15 \%$ in 1992.

\subsection{The Impact of the Initial Wage Gap on Job Mobility}

Table 2 displays separation transitions by labour market experience and the position in the distribution of entry wage differentials, to illustrate the job mobility behaviour of individuals affected by diverse starting conditions. In general, transition rates are decreasing with the individual's labour market experience. Furthermore, workers of the lower quintiles of the distribution of entry wage differentials tend to be more mobile at the beginning of their career. For example, two years after labour market entry, workers with starting wages below the average show employer-to-employer (EE) transition rates ranging from $33.2 \%$ to $27.9 \%$, while the respective transition rates of workers whose entry wage lies above the sample mean only reach about $23.4 \%$ to $25.2 \%$. Transitions from employment to non-participation (EN) show a very similar pattern. For employment-to-unemployment transitions (EU), however, slightly different properties can be observed. Workers with starting wages near the average entry wage and those with positive deviations from the average entry wage seem to have the lowest transition rates, varying from $9.4 \%$ to $9.8 \%$ two years after labour market entry, while workers with negative deviations from the mean entry wage show relatively higher inflows to unemployment, ranging from $10.3 \%$ to almost $15 \%$.

Table 2 further shows the transition rates for direct $\left(\mathrm{EE}^{D}\right)$ and indirect employment changes $\left(\mathrm{EE}^{I D}\right)$. Direct EE flows are again higher for workers from the lower quintiles of the entry wage distribution. Moreover, EE flows with an intervening nonemployment spell increase with negative wage deviations and are least likely to occur for workers with starting wages near or above the average entry wage. Overall, Table 2 suggests that individuals with entry wages below the average entry wage tend to be more mobile.

\footnotetext{
${ }^{9}$ The probability to enter the labour market follows a strongly procyclical pattern. Therefore we argue that the estimated wage losses constitute a lower bound of costs due to unfavourable starting conditions, as the costs of an increased unemployment probability would add.
} 
Table 3 reports the marginal effects obtained from estimating two specifications of a probit model for the three separation flows EE, EN, and EU: (i) a basic specification described in equation (1) (see columns (1), (3) and (5)), and (ii) an extended specification, which includes also interaction variables of entry year effects with worker's employment duration (columns (2), (4) and (6)). The results are generally in line with the literature on job mobility. The estimation results also show that employment duration negatively affects the likelihood of separating. This negative duration dependence may be attributed to the fact that longer tenure is often associated with a better worker-firm match quality. The result that women face a significantly lower risk of job separation than men, irrespective of the destination state, is, however, not in line with other studies on labour market flows, which in general find women to be more mobile than men, and to be more likely to transit from employment to unemployment or nonparticipation, usually because of maternity leave and child care. For our sample, consisting of job starters, these factors appear not to be as important as in a representative sample of female employees.

Concerning the impact of the entry wage gap on transition probabilities, the estimation results largely confirm the results from the descriptive analysis. The probability of an EE or EN flow is increasing with negative and decreasing with positive entry year effects. The marginal effects in the second specification indicate that the higher EE and EN mobility of workers facing a negative entry wage gap is even larger at the beginning of their career and then gradually declines with employment duration, while the lower EE and EN flows for workers with a positive entry wage gap is decreasing with increasing tenure. A different pattern occurs for the outflows to unemployment. Here the estimation results indicate that positive entry year effects do not have a statistically significant impact on the transition probability. Negative entry year wage differentials, however, significantly increase the probability of moving into unemployment. Overall, our estimation results indicate that workers entering the labour market during poor economic conditions tend to be more mobile, which is in line with the evidence presented by Oreopoulos, von Wachter, and Heisz (2008).

The coefficients obtained from estimating the probability of changing jobs directly and indirectly as well as with and without a change in occupation for all workers and for the sup-samples of workers with different skill-levels are shown in Table 4. Positive entry year effects significantly reduce the likelihood of direct employer-to-employer transitions: referring to the whole sample, a one percent increase of the positive entry year effect 
lowers the transition probability by $0.11 \%$. This negative effect appears for all three skill-levels we distinguish in our analysis. Arguably, labour market entrants affected by advantageous economic conditions and earning wages above the average have a lower incentive to search for better-paid jobs. The probability of changing employers through a nonemployment spell, however, is significantly negatively affected by positive entry year effects only for low-skilled workers. Differentiating employer changes that occur with $\left(E E^{O M}\right)$ and without $\left(E E^{O S}\right)$, a change in occupation shows that the latter is not affected by a positive wage gap. Employer changes that are associated with an occupational change, on the other hand, are significantly lower for individuals with positive entry wage gaps (at least for the low- and medium-skilled).

Negative entry year effects, on the other hand, are positively correlated with direct employer-to-employer transitions for all skill-groups and with indirect employer-to-employer transitions for the high-skilled. Considering all workers, an increase of the negative wage differential by one percentage point increases the likelihood of direct and indirect transitions by $0.33 \%$ and $0.16 \%$, respectively. Finally, Table 4 indicates that both, employer changes with and without an accompanied change of the occupation, increase with a negative entry wage differential.

Overall, these results indicate that workers entering the labour market during unfavourable economic situations and earning less than the average entry wage, might feel underpaid and may accept jobs in occupations that do not fit their preferences. These workers have a relatively high incentive to search for better jobs, and are relatively more likely to switch jobs without an intervening nonemployment spell and with and without an occupational change.

\subsection{Adjustment of Entry Year Effects}

To examine the effect of job mobility on entry year wage differentials over time, we compare wages and wage growth between stayers and movers five years after labour market entry. Stayers are defined as workers who stay in their first job. Movers are classified into the following groups: workers who change jobs within the first five years of their labour market career (i) directly, (ii) indirectly, (iii) directly as well as indirectly, and (iv) with and without a change in the occupation. ${ }^{10}$ The distribution of the individuals

\footnotetext{
${ }^{10} \mathrm{By}$ this definition, workers are allowed to switch employers several times within the first five years. Restricting the sample to workers who changed jobs only once leads to very similar, but slightly reduced effects.
} 
in our sample over these categories is shown in Table A.3.

Table 5 presents the results of estimating the log wage on a constant and four dummy variables indicating whether the entry wage differential of an individual is in the first, second, fourth or fifth quintile of the distribution of entry wage differentials. It indicates that entry wage differentials decrease strongly with labour market experience and that this mitigation of entry wage differentials is facilitated by job mobility. For example, at the time of labour market entry, workers in the first quintile of the distribution of entry wage differentials earn $0.71 \mathrm{log}$ points (around 51\%) less than those who received the average entry wage. After five years of labour market experience, this wage gap reduces to 0.20 log points (18\%) when staying with the first employer, 0.07 log points $(6 \%)$ when changing employer directly and $0.10 \log$ points $(6 \%)$ when changing employers indirectly. The reverse pattern could be observed for those who received wages above the average entry wage when they started their career. For those in the fifth quintile of the distribution of entry wage differentials, for example, the initial wage advantage of almost $56 \%$ at the time of entry to those who received average entry wages reduces to $22 \%$ after five years of labor market experienec when they stay with their first employer, to $13 \%$ when they change employers directly and to $11 \%$ when they change employers indirectly. Note further that the lowest wage convergence could be observed for those who change both employers and occupations, which may be explained by a loss of occupation specific human capital.

These patterns are investigated in more detail by estimating equation (3) as described in the previous section. ${ }^{11}$ The estimation results when differentiating stayers as well as movers who changed their employer directly and indirectly are shown in Table 6, while Figure 3 further illustrates the results. The coefficients reported in the first row of this table show the average effect of staying with the initial firm, changing jobs directly as well as changing jobs indirectly. The interaction terms indicate how these main effects are modified when we distinguish between workers entering the labour market in different years. Overall, wages of stayers are $3.8 \%$ below the average. This negative effect is even higher for workers who started their career before 1988, but lower for those who entered the labour market afterwards. The older entry cohorts, suffering from initial wage disadvantages, can benefit from changing employers without an intervening nonemployment spell. While the main effect of direct job mobility lies at about $3.4 \%$, it is even

\footnotetext{
${ }^{11}$ Here we only consider workers who change jobs only directly or indirectly within the first five years. Those who show both types of job mobility (about 18.000 workers) are not included.
} 
higher for these earlier years. Workers entering the labour market in earlier years also benefit strongly from changing employers indirectly. One can observe opposite results for workers who start their career later and initially earn wages above the average: Compared to the main effect, direct and indirect job changes imply a lower wage.

Figure 3 shows the estimated entry year effects at the time of labour market entry and five years later. After five years of potential labour market experience, the wage differentials across workers with different entry years have decreased for both, movers and stayers. This reduction is much stronger when workers change their employers, suggesting that job mobility is an important mechanism for wage convergence across entry cohorts. For example, the $11.1 \%$ wage disadvantage of workers who started their career in 1984 and stay in their first job is reduced to $7.9 \%$, while direct and indirect movers experience a reduction of their initial negative wage differentials to $3.6 \%$ and $0.8 \%$, respectively.

Figure 4 illustrates the wage convergence when differentiating between staying, employer changes that are associated with an occupational change and employer changes without an occupational change. Again, entry wage differentials appear to be mitigated over time with wage convergence being stronger for movers than for stayers. Notably, employer changes that are accompanied by a change in occupation appear to differ not very much from employer mobility without an occupational change, indicating that occupation-specific skills play only a minor role at the beginning of a worker's career.

Finally, Figure 5 shows the respective results for different skill groups. In this analysis, we only differentiate between movers and stayers and do not consider different types of job mobility. The first noteworthy result is that the variation of entry wage differentials is lowest for the high-skilled, followed by the low- and medium-skilled. Second, for all skill groups, entry wage differentials appear to narrow over time, with the convergence being higher for movers if compared to stayers. Finally, wage convergence is lowest for low-skilled who stay with their first employer, followed by the medium- and high-skilled. ${ }^{12}$

\subsection{Sensitivity Analysis}

As discussed in Section 4 the OLS results reported in Table 6 may be biased because of the endogenous nature of the mobility decision. Therefore,

\footnotetext{
${ }^{12}$ The detailed estimation results underlying these figures are available from the authors upon request.
} 
we perform the same regression using the instruments described in Section 4.2. In particular, we use the industry employment growth rate and a mass-layoff indicator as instruments for voluntary and involuntary job mobility, respectively. Both instruments appear to be strong predictors of the workers' probability to change jobs. Most importantly, an F-test of joint significance of the instruments suggests that our results do not suffer from a problem of weak instruments. Table 7 shows that the IV results differ from the respective OLS results. In particular, indirect mobility now has a significantly negative effect on wages five years after labour market entry, while staying in the same firm and direct job-to-job mobility have a positive effect, with the latter being most beneficial. Figure 6 shows, however, that these changes in the estimation results do change our conclusions concerning wage convergence qualitatively. Using again the 1984 entry cohort as an example, the $11.1 \%$ wage disadvantage of this cohort reduces to $5.8 \%$ five years after labour market entry. Direct and indirect movers experience a reduction of their initial negative wage differentials to $1.4 \%$ and $1.8 \%$, respectively.

In order to test the robustness of our results, we further addressed the endogenous nature of the labour market entry decision. ${ }^{13}$ It might be the case that in times of unfavourable economic conditions, individuals decide not to enter the labour market and postpone their career start by getting further education. We therefore perform a separate analysis for workers who start working after finishing their apprenticeship. These workers are of particular interest because they are not easily able to respond to fluctuations in economic conditions and are thus unlikely to defer the starting point of their labour market career. The regression results indicate that workers who start their career after an apprenticeship and who are affected by positive wage deviations experience almost the same transition probabilities as the full sample. With respect to negative initial wage differentials, however, apprentices are more likely to separate from their employer. Being less able to postpone their labour market entry and to avoid poor match qualities, unfavourable economic conditions have a stronger effect on their transition probabilities. Estimating the apprentices' entry wage differentials and their reduction within the first five years of labour market experience leads to very similar results as for the whole sample.

In a second robustness test, we conduct our analysis using the predicted instead of the actual year of entry, i.e. we use the year the worker should

\footnotetext{
${ }^{13}$ The results from the robustness tests are not displayed in this paper. They are available from the authors upon request.
} 
have entered the labour market given his age and education. ${ }^{14}$ Again, this leads to qualitatively very similar results as for the whole sample. Quantitatively, year of entry effects on wages are found to be somewhat smaller. This can be explained by the fact that workers who do not postpone their labour market entry generally find jobs with characteristics which are relatively independent of economic conditions. To take an example, workers who do not postpone their labour market entry in a recession are likely to have found a relatively good job, i.e. they do not contribute to potential negative entry effects.

Up to now, we have modeled the effect of the economic situation at the time of labour market entry on wages in a very general way by using entry year dummies rather than investigating potential sources of entry wage differentials directly. In an attempt to investigate these potential sources of entry wage differentials more closely, we exchanged the entry year dummies $C_{j}$ in the wage equations (2) and (3) by the unemployment rate as a general indicator of the labour market situation and the size of the entry cohort as a supply shock indicator in the year of labour market entry. ${ }^{15}$ Table 8 shows that both the unemployment rate and the cohort size at the time of labour market entry have a negative effect on entry wages and wages five years after labor market entry, with the latter being significantly smaller. Similarly to the results discussed above, direct employer changes have a significant positive effect on wages, while indirect job changes do not have a significant impact. Also in accordance with the results reported above, the results in Table 8 imply that employer changes have a positive effect on wages irrespective of whether they are accompanied by an occupational change or not. This positive effect, however, is significantly higher for those who change employers without changing the occupation. Finally, the estimated coefficients for the interaction variables of the unemployment rate and the cohort size in the year of labour market entry with the mobility indicators show that job mobility appears to reduce wage differentials resulting from different initial labour market conditions.

\section{Conclusion}

This paper investigates the relationship between entry year effects in wages and workers' mobility behaviour early in their career, employing a large

\footnotetext{
${ }^{14}$ The results are available from the authors upon request.

${ }^{15}$ The unemployment rates are measured at the level of the German Länder and come from the official statistics of the German Federal Employment Agency. The cohort size was computed from the IABS by the authors.
} 
German administrative panel data set covering the time period from 1975 to 2004. In a first step, we model the effect of the economic condition at the time of labour market entry on the probability of experiencing different types of job transitions. Entry wage differentials are found to be an important determinant of job mobility. For all types of transitions we can show that workers affected by poor economic starting conditions are more likely to separate from their job. For example, workers who earn wages $20 \%$ below the mean entry wage face a $6.6 \%$ higher risk to directly switch employers than workers with average starting wages.

In a second step, we investigate whether job mobility contributes to the mitigation of entry wage differentials. We find that wage differentials across entry cohorts decrease with labour market experience. Moreover, the estimation results show that cohorts with entry wage advantages can benefit from direct job changes, but are adversely affected by employer transitions with an intervening unemployment spell. For workers with initial wage disadvantages, however, job mobility in general increases wages. The same holds for employer changes with and without an occupational change, with the later being more beneficial. Furthermore, these results are similar for different skill groups. Finally, the results are robust towards various sensitivity checks, including the consideration of a potential endogeneity problem that emerges from the possibility that mobility is likely to be correlated with unobserved individual and job characteristics affecting earnings by applying an instrumental-variable approach.

Overall, our empirical results show that job mobility indeed operates as an adjustment mechanism that leads to a reduction of wage differentials between workers entering the labour market at different points in time. These are good news for those who enter the labour market during the current economic crisis. Even though they may suffer from lower entry wages, they will experience a faster wage growth in the years to come, especially if they are mobile. 


\section{References}

Abowd, J. M., F. Kramarz, and S. Roux (2006): "Wages, mobility and firm performance: Advantages and insights from using matched worker-firm data," The Economic Journal, 116, F245-F285.

Altonji, J. G., and R. A. Shakotko (1987): "Do Wages Rise with Job Seniority," Review of Economics and Statistics, 54(3), 437-460.

Antel, J. J. (1986): "Human Capital Investment Specialization and the Wage Effects of Voluntary Labor Mobility," Review of Economics and Statistics, 68(3), 477-483.

Azariadis, C. (1975): "Implicit Contracts and Underemployment Equilibria," The Journal of Political Economy, 83(6), 1183-1202.

Baker, G., M. Gibbs, and B. Holmstrom (1994): "The Wage Policy of a Firm," Quarterly Journal of Economics, 109, 881-919.

Bartel, A. P., and G. J. Borjas (1978): "Wage Growth and Job Turnover: An Empirical Analysis," NBER Working paper 285, National Bureau of Economic Research.

Beaudry, P., and J. DiNardo (1991): "The Effect of Implicit Contracts and the Movement of Wages over the Business Cycle," Journal of Political Economy, 99(4), 665-688.

Becker, G. (1975): "Human Capital," 2nd ed. university of chicago press for the nber, Chicago, IL.

Bender, S., A. Haas, and C. Klose (2000): "IAB employment subsample 1975-1995. Opportunities for analysis provided by the anonymised subsample," IZA Discussion Paper 117, Institute for the Study of Labor (IZA).

Berger, M. C. (1989): "Demographic cycles, cohort size, and earnings," Demography, 26(2), 311-321.

BILS, M. J. (1985): "Real Wages over the Business Cycle: Evidence from Panel Data," Journal of Political Economy, 93(4), 666-689.

Bloom, D. E., and R. B. Freeman (1986): "The Youth Problem: Age or Generational Crowding," NBER Working Paper 1829, National Bureau of Economic Research. 
Bloom, D. E., R. B. Freeman, and S. Korenman (1987): "The Labour Market Consequences of Generational Crowding," European Journal of Population, 3, 131-176.

Burdett, K. (1979): "A Theory of Employee Job Search and Quit Rates," American Economic Review, 68(1), 212-220.

Fitzenberger, B., A. Osikumino, and R. Völter (2006): "Imputation Rules to Improve the Education Variable in the IAB Employment Subsample," Schmollers Jahrbuch / Journal of Applied Social Science Studies, 126(3), 405-436.

Fitzenberger, B., and R. A. Wilke (2006): "Unemployment Durations in West -Germany Before and After the Reform of the Unemployment Compensation System during the 1980ties," Discussion paper, Goethe University Frankfurt.

Freeman, R. B. (1979): "The Effect of Demographic Factors on AgeEarnings Profiles," The Journal of Human Resources, 14, 289-318.

Gibbons, R., and L. Katz (1991): "Layoffs and Lemons," Journal of Labor Economics, 9(4), 351-380.

Gibbons, R., and M. Waldman (2004): "Task-Specific Human Capital," AEA Papers and Proceedings, 94, 203-207.

Goeggel, K., and T. Zwick (2009): "Good Occupation - Bad Occupation? The Quality of Apprenticeship Training," Discussion Paper 09-024, ZEW.

Harris, M., and B. Holmstrom (1982): "A Theory of Wage Dynamics," Review of Economic Studies, 49, 315-333.

JANn, B. (2005): "DEVCON: Stata module to apply the deviation contrast transform to estimation results," Statistical Software Components, Boston College Department of Economics.

Jovanovic, B. (1979): "Job Matching and the Theory of Labor Turnover," Journal of Political Economy, 87, 972-990.

Kletzer, L. G., and R. W. Fairlie (2003): "The Long-Term Costs of Job Displacement Among Young Workers," Industrial Labor Relations Review, 56(4), 682-698. 
Martins, P. S., G. Solon, and J. P. Thomas (2010): "Measuring What Employers Really Do about Entry Wages over the Business Cycle," IZA Discussion Papers 4757, Institute for the Study of Labor (IZA).

McLaughlin, K. J. (1991): "A Theory of Quits and Layoffs with Efficient Turnover," Journal of Political Economy, 99(1), 1-29.

Murphy, K. M., M. Plant, and F. Welch (1988): "Cohort Size and Earnings in the United States," in Economics of Changing Age Distributions in Developing Countries, ed. by R. D. Lee, W. B. Arthur, and G. Rodgers, pp. 39-58. Oxford University Press, Oxford.

Murphy, K. M., and R. H. Topel (1985): "Estimation and Inference in Two-Step Econometric Models," Journal of Business and Economic Statistics, 3(4), 370-379.

Okun, A. M. (1973): "Upward Mobility in a High-Pressure Economy," Brookings Papers of Economic Activity, 1, 207-252.

Oreopoulos, P., T. von Wachter, and A. Heisz (2008): "The Shortand Long-Term Career Effects of Graduating in a Recession: Hysteresis and Heterogeneity in the Market for College Graduates," IZA Discussion Paper 3578, Institute for the Study of Labor (IZA).

Oyer, P. (2006): "The Macro-Foundations of Microeconomics: Initial Labor Market Conditions and Long-Term Outcomes for Economists," NBER Working Papers 12157, National Bureau of Economic Research.

Perez, J. I. G., and Y. R. SAnz (2005): "Wage Changes Through Job Mobility in Europe: A Multinomial Endogenous Switching Approach," Labour Economics, 12, 531-555.

Ravn, M. O., and H. Uhlig (2002): "On adjusting the Hodrick-Prescott filter for the frequency of observations," The Review of Economics and Statistics, MIT Press, 84(2), 371-375.

Reder, M. (1955): "The Theory of Occupational Wage Differentials," American Economic Review, 45, 833-852.

Shin, D. (1994): "Cyclicality of Real Wages among Young Men," Economics Letters, 46(2), 137-142.

Solon, G., R. Barsky, and J. A. Parker (1994): "Measuring the Cyclicality of Real Wages: How Important is Composition Bias?," Quarterly Journal of Economics, 109(1), 1-25. 
Topel, R. H., And M. P. Ward (1992): "Job Mobility and the Careers of Young Men," Quarterly Journal of Economics, 107(2), 439-479.

von Wachter, T., and S. Bender (2006): "In the Right Place at the Wrong Time: The Role of Firms and Luck in Young Workers Careers," American Economic Review, 96(5), 1679-1705.

(2008): "Do Initial Conditions Persist Between Firms? An Analysis of Firm-Entry Cohort Effects and Job Losers using Matched Employer-Employee Data," in The Analysis of Firms and Employees: Quantitative and Qualitative Approaches, ed. by S. Bender, J. Lane, K. L. Shaw, F. Andersson, and T. von Wachter. University Chicago Press.

Welch, F. (1979): "The Effect of Cohort Size on Earnings: The Baby Boom Babies' Financial Bust," Journal of Political Economy, 87(5), 6597. 


\section{Tables and Figures}

Table 1: Year effects in starting wages

\begin{tabular}{|c|c|c|c|c|c|c|}
\hline \multirow{2}{*}{$\begin{array}{l}\text { Year of } \\
\text { entry }\end{array}$} & \multicolumn{2}{|c|}{$\overline{(1)}$} & \multicolumn{2}{|c|}{$\overline{(2)}$} & \multicolumn{2}{|c|}{$\overline{\overline{(3)}}$} \\
\hline & Coeff. & (S. D.) & Coeff. & (S. D.) & Coeff. & (S. D.) \\
\hline 1980 & $-0.214^{*}$ & $(0.004)$ & $-0.152^{*}$ & $(0.004)$ & $-0.020^{*}$ & $(0.004)$ \\
\hline 1981 & $-0.217^{*}$ & $(0.004)$ & $-0.156^{*}$ & $(0.004)$ & $-0.037^{*}$ & $(0.006)$ \\
\hline 1982 & $-0.242^{*}$ & $(0.005)$ & $-0.186^{*}$ & $(0.004)$ & $-0.081^{*}$ & $(0.006)$ \\
\hline 1983 & $-0.230^{*}$ & $(0.005)$ & $-0.184^{*}$ & $(0.004)$ & $-0.093^{*}$ & $(0.005)$ \\
\hline 1984 & $-0.225^{*}$ & $(0.005)$ & $-0.187^{*}$ & $(0.004)$ & $-0.111^{*}$ & $(0.005)$ \\
\hline 1985 & $-0.197^{*}$ & $(0.005)$ & $-0.169^{*}$ & $(0.004)$ & $-0.106^{*}$ & $(0.005)$ \\
\hline 1986 & $-0.145^{*}$ & $(0.005)$ & $-0.122^{*}$ & $(0.004)$ & $-0.074^{*}$ & $(0.004)$ \\
\hline 1987 & $-0.113^{*}$ & $(0.005)$ & $-0.096^{*}$ & $(0.004)$ & $-0.061^{*}$ & $(0.004)$ \\
\hline 1988 & $-0.083^{*}$ & $(0.005)$ & $-0.082^{*}$ & $(0.004)$ & $-0.061^{*}$ & $(0.004)$ \\
\hline 1989 & $-0.052^{*}$ & $(0.004)$ & $-0.057^{*}$ & $(0.004)$ & $-0.050^{*}$ & $(0.004)$ \\
\hline 1990 & 0.001 & $(0.005)$ & $-0.013^{*}$ & $(0.004)$ & $-0.020^{*}$ & $(0.004)$ \\
\hline 1991 & $0.057^{*}$ & $(0.005)$ & $0.038^{*}$ & $(0.004)$ & $0.017^{*}$ & $(0.004)$ \\
\hline 1992 & $0.212^{*}$ & $(0.005)$ & $0.180^{*}$ & $(0.004)$ & $0.145^{*}$ & $(0.004)$ \\
\hline 1993 & $0.214^{*}$ & $(0.005)$ & $0.191^{*}$ & $(0.004)$ & $0.142^{*}$ & $(0.005)$ \\
\hline 1994 & $0.210^{*}$ & $(0.005)$ & $0.178^{*}$ & $(0.005)$ & $0.115^{*}$ & $(0.005)$ \\
\hline 1995 & $0.234^{*}$ & $(0.005)$ & $0.186^{*}$ & $(0.005)$ & $0.110^{*}$ & $(0.006)$ \\
\hline 1996 & $0.211^{*}$ & $(0.006)$ & $0.177^{*}$ & $(0.005)$ & $0.087^{*}$ & $(0.006)$ \\
\hline 1997 & $0.179^{*}$ & $(0.006)$ & $0.146^{*}$ & $(0.005)$ & $0.042^{*}$ & $(0.006)$ \\
\hline 1998 & $0.188^{*}$ & $(0.006)$ & $0.138^{*}$ & $(0.005)$ & $0.020^{*}$ & $(0.007)$ \\
\hline 1999 & $0.213^{*}$ & $(0.006)$ & $0.169^{*}$ & $(0.005)$ & $0.036^{*}$ & $(0.007)$ \\
\hline Individual characteristics & No & & Yes & & Yes & \\
\hline Firm charactersitics & No & & Yes & & Yes & \\
\hline Time Trend & No & & No & & Yes & \\
\hline
\end{tabular}

Source: Authors' calculations, based on IABS 1975-2004.

Note: Dependent variable is the log real daily wage. Year effects are calculated as deviations from the grand mean starting wage. Person cahracteristics include dummy variables for gender and skill level, while firm controls include dummy variables for establishment size and industry. The three specifications differ by the inclusion of observable controls only. *: statistically significant at least at the 5\%-level. 
Table 2: Mobility statistics by deviation from mean entry wage

\begin{tabular}{llccccccc}
\hline Distribution of entry & Experience & \multicolumn{7}{c}{ Worker flow rates } \\
\cline { 3 - 8 } wage differentials & & $\mathrm{EN}$ & $\mathrm{EU}$ & $\mathrm{EE}$ & $\mathrm{EE}^{D}$ & $\mathrm{EE}^{I D}$ & $\mathrm{EE}^{O S}$ & $\mathrm{EE}^{O M}$ \\
\hline 1st quintile & 1st year & 0.242 & 0.169 & 0.368 & 0.235 & 0.133 & 0.195 & 0.173 \\
& 3rd year & 0.162 & 0.147 & 0.332 & 0.224 & 0.108 & 0.173 & 0.159 \\
\multirow{3}{*}{ 2nd quintile } & 5th year & 0.132 & 0.116 & 0.273 & 0.196 & 0.077 & 0.142 & 0.131 \\
& 1st year & 0.221 & 0.102 & 0.323 & 0.228 & 0.095 & 0.179 & 0.144 \\
& 3rd year & 0.142 & 0.103 & 0.279 & 0.200 & 0.079 & 0.149 & 0.130 \\
3rd quintile & 5th year & 0.120 & 0.092 & 0.235 & 0.171 & 0.064 & 0.123 & 0.112 \\
& 1st year & 0.243 & 0.111 & 0.313 & 0.222 & 0.091 & 0.167 & 0.146 \\
4th quintile & 3rd year & 0.129 & 0.098 & 0.267 & 0.193 & 0.074 & 0.141 & 0.126 \\
& 5th year & 0.122 & 0.087 & 0.229 & 0.168 & 0.061 & 0.122 & 0.107 \\
5th quintile & 1st year & 0.241 & 0.107 & 0.297 & 0.204 & 0.093 & 0.163 & 0.134 \\
& 3rd year & 0.118 & 0.094 & 0.252 & 0.177 & 0.075 & 0.138 & 0.114 \\
& 5th year & 0.122 & 0.083 & 0.214 & 0.152 & 0.062 & 0.116 & 0.098 \\
& 1st year & 0.220 & 0.097 & 0.258 & 0.176 & 0.082 & 0.147 & 0.111 \\
& 3rd year & 0.108 & 0.097 & 0.234 & 0.156 & 0.078 & 0.131 & 0.103 \\
& 5th year & 0.111 & 0.078 & 0.200 & 0.143 & 0.057 & 0.112 & 0.088 \\
\hline
\end{tabular}

Source: Authors' calculations, based on IABS 1975-2004.

Note: The flow definitions are in Table A.1. The 1st quintile represents the bottom $20 \%$ of the wage distribution, the 5 th quintile represents the top $20 \%$. 
Table 3: Entry Wage Differentials and Job Mobility: Probit Estimation Results

\begin{tabular}{|c|c|c|c|c|c|c|}
\hline & \multicolumn{2}{|c|}{$\mathrm{EE}$} & \multicolumn{2}{|c|}{$\overline{\mathrm{EU}}$} & \multicolumn{2}{|c|}{$\overline{\mathrm{EN}}$} \\
\hline & (1) & $(2)$ & $(3)$ & $(4)$ & $(5)$ & $(6)$ \\
\hline \multirow[t]{2}{*}{ Positive wage gap } & $-0.0016^{*}$ & $-0.0008^{*}$ & -0.0013 & -0.0012 & $-0.0015^{*}$ & $-0.0077^{*}$ \\
\hline & $(0.0004)$ & $(0.0005)$ & $(0.0007)$ & $(0.0008)$ & $(0.0001)$ & $(0.0001)$ \\
\hline \multirow[t]{2}{*}{ Negative wage gap } & $0.0024^{*}$ & $0.0035^{*}$ & $0.0028^{*}$ & $0.0030^{*}$ & $0.0046^{*}$ & $0.0056^{*}$ \\
\hline & $(0.0003)$ & $(0.0003)$ & $(0.0002)$ & $(0.0004)$ & $(0.0003)$ & $(0.0004)$ \\
\hline \multirow{2}{*}{$\begin{array}{l}\text { Positive wage gap } \\
* \text { Tenure }\end{array}$} & & $-0.0004^{*}$ & & $-0.0003^{*}$ & & $0.0008^{*}$ \\
\hline & & $(0.0001)$ & & $(0.0002)$ & & $(0.0000)$ \\
\hline \multirow{2}{*}{$\begin{array}{l}\text { Negative wage gap } \\
* \text { Tenure }\end{array}$} & & $-0.0002^{*}$ & & 0.0002 & & $-0.0001^{*}$ \\
\hline & & $(0.0000)$ & & $(0.0002)$ & & $(0.0000)$ \\
\hline \multicolumn{7}{|c|}{ Gender (Reference: Male) } \\
\hline \multirow[t]{2}{*}{ Female } & $-0.0393^{*}$ & $-0.0388^{*}$ & $-0.0395^{*}$ & $-0.0395^{*}$ & $-0.0162^{*}$ & $-0.0162^{*}$ \\
\hline & $(0.0029)$ & $(0.0029)$ & $(0.0015)$ & $(0.0015)$ & $(0.0003)$ & $(0.0003)$ \\
\hline \multicolumn{7}{|c|}{ Employment Duration (Reference: $0-6$ months) } \\
\hline \multirow[t]{2}{*}{ 7-12 months } & $-0.1777^{*}$ & $-0.1715^{*}$ & $-0.0544^{*}$ & $-0.0536^{*}$ & $-0.0095^{*}$ & $-0.0115^{*}$ \\
\hline & $(0.0030)$ & $(0.0031)$ & $(0.0013)$ & $(0.0014)$ & $(0.0003)$ & $(0.0003)$ \\
\hline \multirow[t]{2}{*}{ 13-18 months } & $-0.1925^{*}$ & $-0.1812^{*}$ & $-0.0895^{*}$ & $-0.0885^{*}$ & $-0.0094^{*}$ & $-0.0133^{*}$ \\
\hline & $(0.0032)$ & $(0.0034)$ & $(0.0013)$ & $(0.0013)$ & $(0.0004)$ & $(0.0003)$ \\
\hline \multirow[t]{2}{*}{ 19-24 months } & $-0.2704^{*}$ & $-0.2570^{*}$ & $-0.1066^{*}$ & $-0.1054^{*}$ & $-0.0129^{*}$ & $-0.0182^{*}$ \\
\hline & $(0.0030)$ & $(0.0034)$ & $(0.0012)$ & $(0.0013)$ & $(0.0004)$ & $(0.0003)$ \\
\hline \multirow[t]{2}{*}{ 25-36 months } & $-0.2985^{*}$ & $-0.2785^{*}$ & $-0.1274^{*}$ & $-0.1256^{*}$ & $-0.0106^{*}$ & $-0.0190^{*}$ \\
\hline & $(0.0027)$ & $(0.0035)$ & $(0.0011)$ & $(0.0013)$ & $(0.0003)$ & $(0.0003)$ \\
\hline \multirow[t]{2}{*}{ 37-60 months } & $-0.3892^{*}$ & $-0.3592^{*}$ & $-0.1521^{*}$ & $-0.1490^{*}$ & $0.0381^{*}$ & $0.0129^{*}$ \\
\hline & $(0.0025)$ & $(0.0041)$ & $(0.0011)$ & $(0.0016)$ & $(0.0005)$ & $(0.0005)$ \\
\hline No. of observations & \multicolumn{2}{|c|}{$2,832,804$} & \multicolumn{2}{|c|}{$2,832,804$} & \multicolumn{2}{|c|}{$2,832,804$} \\
\hline
\end{tabular}

Source: Authors' calculations, based on IABS 1975-2004.

Note: Standard errors in parentheses. *: statistically significant at least at the 5\%-level. Each regression includes industry, establishment size, year, two dummy variables for the skill-level of the individual and quarterly dummies. EE: employer-to-employer flows, EU: employmentto-unemployment flows, $\mathrm{EN}$ : employment-to-nonparticipation flows, $\mathrm{EE}^{D}$ : direct employer-toemployer flows, $\mathrm{EE}^{I} D$ : indirect employer-to-employer flows (see Table A.1). 
Table 4: Entry Wage Differentials, Different Types of Job Mobility and Skill Levels: Probit Estimation Results

\begin{tabular}{|c|c|c|c|c|c|}
\hline & $\begin{array}{l}\text { Entry Wage } \\
\text { Gap }\end{array}$ & $\begin{array}{l}\text { All } \\
\text { All }\end{array}$ & $\begin{array}{l}\text { Low- } \\
\text { skilled }\end{array}$ & $\begin{array}{l}\text { Medium- } \\
\text { skilled }\end{array}$ & $\begin{array}{l}\text { High- } \\
\text { skilled }\end{array}$ \\
\hline \multirow[t]{4}{*}{$\mathrm{EE}$} & Positive & $-0.0016^{*}$ & $-0.0013^{*}$ & $-0.0016^{*}$ & $-0.0020^{*}$ \\
\hline & & $(0.0004)$ & $(0.0002)$ & $(0.0004)$ & $(0.0005)$ \\
\hline & Negative & $0.0024^{*}$ & 0.0002 & $0.0026^{*}$ & $0.0018^{*}$ \\
\hline & & $(0.0003)$ & $(0.0003)$ & $(0.0003)$ & $(0.0004)$ \\
\hline \multirow[t]{4}{*}{$\mathrm{EE}^{D}$} & Positive & $-0.0011^{*}$ & $-0.0009^{*}$ & $-0.0012^{*}$ & $-0.0016^{*}$ \\
\hline & & $(0.0003)$ & $(0.0002)$ & $(0.0003)$ & $(0.0004)$ \\
\hline & Negative & $0.0033^{*}$ & $0.0006^{*}$ & $0.0036^{*}$ & $0.0012^{*}$ \\
\hline & & $(0.0002)$ & $(0.0002)$ & $(0.0002)$ & $(0.0003)$ \\
\hline \multirow[t]{4}{*}{$\mathrm{EE}^{I D}$} & Positive & -0.0005 & $-0.0007^{*}$ & -0.0004 & -0.0006 \\
\hline & & $(0.0009)$ & $(0.0003)$ & $(0.0010)$ & $(0.0012)$ \\
\hline & Negative & $0.0016^{*}$ & -0.0002 & 0.0015 & $0.0018^{*}$ \\
\hline & & $(0.0002)$ & $(0.0002)$ & $(0.0002)$ & $(0.0006)$ \\
\hline \multirow[t]{4}{*}{$\mathrm{EE}^{O S}$} & Positive & -0.0003 & 0.0002 & -0.0004 & -0.0011 \\
\hline & & $(0.0005)$ & $(0.0008)$ & $(0.0005)$ & $(0.0007)$ \\
\hline & Negative & $0.0025^{*}$ & $0.0014^{*}$ & $0.0026^{*}$ & $0.0023^{*}$ \\
\hline & & $(0.0003)$ & $(0.0005)$ & $(0.0003)$ & $(0.0005)$ \\
\hline \multirow[t]{4}{*}{$\mathrm{EE}^{O M}$} & Positive & $-0.0006^{*}$ & $-0.0013^{*}$ & $-0.0005^{*}$ & -0.0004 \\
\hline & & $(0.0003)$ & $(0.0005)$ & $(0.0003)$ & $(0.0003)$ \\
\hline & Negative & $0.0022^{*}$ & 0.0004 & $0.0024^{*}$ & $0.0026^{*}$ \\
\hline & & $(0.0007)$ & $(0.0006)$ & $(0.0007)$ & $(0.0007)$ \\
\hline \multicolumn{2}{|l|}{ No. of o } & $2,832,804$ & 537,063 & $2,114,443$ & 181,298 \\
\hline
\end{tabular}

Source: Authors' calculations, based on IABS 1975-2004.

Note: Standard errors in parentheses. *: statistically significant at least at the 5\%-level. Each regression includes industry, establishment size, year, and quarterly dummies. EE: employer-to-employer flows, $\mathrm{EE}^{D}$ : direct employer-to-employer flows, $\mathrm{EE}^{I D}$ : indirect employer-to-employer flows, $\mathrm{EE}^{O S}$ : employer-to-employer flows without changing occupations, $\mathrm{EE}^{O M}$ : employer-to-employer flows with changing occupations (see Table A.1).

Table 5: Wage Differentials Five Years After Labour Market Entry: Descriptive Analysis

\begin{tabular}{lccccccc}
\hline \hline Distribution of entry & At entry & \multicolumn{7}{c}{ Five years after entry } \\
\cline { 3 - 7 } wage differentials & & Stayer & $\mathrm{EE}$ & $\mathrm{EE}^{D}$ & $\mathrm{EE}^{I D}$ & $\mathrm{EE}^{O S}$ & $\mathrm{EE}^{O M}$ \\
\hline const. (3rd quintile) & $3.775^{*}$ & $4.205^{*}$ & $4.257^{*}$ & $4.262^{*}$ & $4.246^{*}$ & $4.201^{*}$ & $4.313^{*}$ \\
& $(0.002)$ & $(0.005)$ & $(0.004)$ & $(0.005)$ & $(0.011)$ & $(0.005)$ & $(0.006)$ \\
1st quintile & $-0.710^{*}$ & $-0.202^{*}$ & $-0.079^{*}$ & $-0.065^{*}$ & $-0.099^{*}$ & $-0.116^{*}$ & $-0.044^{*}$ \\
& $(0.002)$ & $(0.004)$ & $(0.004)$ & $(0.005)$ & $(0.012)$ & $(0.005)$ & $(0.006)$ \\
2nd quintile & $-0.248^{*}$ & $-0.066^{*}$ & $-0.045^{*}$ & $-0.031^{*}$ & $-0.051^{*}$ & $-0.052^{*}$ & $-0.026^{*}$ \\
& $(0.002)$ & $(0.004)$ & $(0.004)$ & $(0.005)$ & $(0.012)$ & $(0.005)$ & $(0.006)$ \\
4th quintile & $0.195^{*}$ & $0.065^{*}$ & $0.043^{*}$ & $0.041^{*}$ & $0.051^{*}$ & $0.064^{*}$ & $0.031^{*}$ \\
& $(0.002)$ & $(0.004)$ & $(0.004)$ & $(0.004)$ & $(0.012)$ & $(0.005)$ & $(0.006)$ \\
5th quintile & $0.442^{*}$ & $0.197^{*}$ & $0.105^{*}$ & $0.123^{*}$ & $0.103^{*}$ & $0.146^{*}$ & $0.072^{*}$ \\
& $(0.001)$ & $(0.003)$ & $(0.003)$ & $(0.003)$ & $(0.008)$ & $(0.003)$ & $(0.004)$ \\
\hline
\end{tabular}

Source: Authors' calculations, based on IABS 1975-2004.

Note: See notes to Table 2. Coefficients are estimated by regressing wage on the 1st, 2nd, 4 th and 5 th quintile. ${ }^{*}$ : statistically significant at least at the $5 \%$-level. 
Table 6: OLS-Estimation of entry year effects five years after labour market entry

\begin{tabular}{|c|c|c|c|c|c|c|c|c|}
\hline & Coeff. & (S. D.) & & Coeff. & (S. D.) & & Coeff. & (S. D.) \\
\hline Stay & $-0.038^{*}$ & $(0.002)$ & $\mathrm{EE}^{D}$ & $0.034^{*}$ & $(0.002)$ & $\mathrm{EE}^{I D}$ & 0.003 & $(0.003)$ \\
\hline 1980 & $-0.091^{*}$ & $(0.002)$ & $1980 \cdot \mathrm{EE}^{D}$ & $0.038^{*}$ & $(0.003)$ & $1980 \cdot \mathrm{EE}^{I D}$ & $0.055^{*}$ & $(0.004)$ \\
\hline 1981 & $-0.084^{*}$ & $(0.002)$ & $1981 \cdot \mathrm{EE}^{D}$ & $0.025^{*}$ & $(0.003)$ & $1981 \cdot \mathrm{EE}^{I D}$ & $0.044^{*}$ & $(0.004)$ \\
\hline 1982 & $-0.101^{*}$ & $(0.002)$ & $1982 \cdot \mathrm{EE}^{D}$ & $0.042^{*}$ & $(0.003)$ & $1982 \cdot \mathrm{EE}^{I D}$ & $0.060 *$ & $(0.004)$ \\
\hline 1983 & $-0.099^{*}$ & $(0.002)$ & $1983 \cdot \mathrm{EE}^{D}$ & $0.061^{*}$ & $(0.003)$ & $1983 \cdot \mathrm{EE}^{I D}$ & $0.074^{*}$ & $(0.004)$ \\
\hline 1984 & $-0.079^{*}$ & $(0.002)$ & $1984 \cdot \mathrm{EE}^{D}$ & $0.043^{*}$ & $(0.003)$ & $1984 \cdot \mathrm{EE}^{I D}$ & $0.071^{*}$ & $(0.005)$ \\
\hline 1985 & $-0.058^{*}$ & $(0.002)$ & $1985 \cdot \mathrm{EE}^{D}$ & $0.035^{*}$ & $(0.003)$ & $1985 \cdot \mathrm{EE}^{I D}$ & $0.048^{*}$ & $(0.005)$ \\
\hline 1986 & $-0.027^{*}$ & $(0.002)$ & $1986 \cdot \mathrm{EE}^{D}$ & $0.030 *$ & $(0.003)$ & $1986 \cdot \mathrm{EE}^{I D}$ & $0.034^{*}$ & $(0.005)$ \\
\hline 1987 & $-0.014^{*}$ & $(0.002)$ & $1987 \cdot \mathrm{EE}^{D}$ & $0.032^{*}$ & $(0.003)$ & $1987 \cdot \mathrm{EE}^{I D}$ & $0.028^{*}$ & $(0.005)$ \\
\hline 1988 & -0.002 & $(0.002)$ & $1988 \cdot \mathrm{EE}^{D}$ & $0.028^{*}$ & $(0.003)$ & $1988 \cdot \mathrm{EE}^{I D}$ & $0.029^{*}$ & $(0.006)$ \\
\hline 1989 & $0.023^{*}$ & $(0.002)$ & $1989 \cdot \mathrm{EE}^{D}$ & $0.025^{*}$ & $(0.003)$ & $1989 \cdot \mathrm{EE}^{I D}$ & 0.001 & $(0.006)$ \\
\hline 1990 & $0.047^{*}$ & $(0.001)$ & $1990 \cdot \mathrm{EE}^{D}$ & 0.005 & $(0.003)$ & $1990 \cdot \mathrm{EE}^{I D}$ & $-0.035^{*}$ & $(0.004)$ \\
\hline 1991 & $0.052^{*}$ & $(0.002)$ & $1991 \cdot \mathrm{EE}^{D}$ & $-0.011^{*}$ & $(0.003)$ & $1991 \cdot \mathrm{EE}^{I D}$ & $-0.013^{*}$ & $(0.006)$ \\
\hline 1992 & $0.086^{*}$ & $(0.002)$ & $1992 \cdot \mathrm{EE}^{D}$ & $-0.043^{*}$ & $(0.003)$ & $1992 \cdot \mathrm{EE}^{I D}$ & $-0.059 *$ & $(0.005)$ \\
\hline 1993 & $0.073^{*}$ & $(0.002)$ & $1993 \cdot \mathrm{EE}^{D}$ & $-0.055^{*}$ & $(0.004)$ & $1993 \cdot \mathrm{EE}^{I D}$ & $-0.043^{*}$ & $(0.006)$ \\
\hline 1994 & $0.062^{*}$ & $(0.002)$ & $1994 \cdot \mathrm{EE}^{D}$ & $-0.043^{*}$ & $(0.004)$ & $1994 \cdot \mathrm{EE}^{I D}$ & $-0.059^{*}$ & $(0.006)$ \\
\hline 1995 & $0.059^{*}$ & $(0.002)$ & $1995 \cdot \mathrm{EE}^{D}$ & $-0.054^{*}$ & $(0.004)$ & $1995 \cdot \mathrm{EE}^{I D}$ & $-0.068^{*}$ & $(0.006)$ \\
\hline 1996 & $0.047^{*}$ & $(0.001)$ & $1996 \cdot \mathrm{EE}^{D}$ & $-0.045^{*}$ & $(0.004)$ & $1996 \cdot \mathrm{EE}^{I D}$ & $-0.060^{*}$ & $(0.006)$ \\
\hline 1997 & $0.037^{*}$ & $(0.003)$ & $1997 \cdot \mathrm{EE}^{D}$ & $-0.033^{*}$ & $(0.004)$ & $1997 \cdot \mathrm{EE}^{I D}$ & $-0.038^{*}$ & $(0.006)$ \\
\hline 1998 & $0.050^{*}$ & $(0.003)$ & $1998 \cdot \mathrm{EE}^{D}$ & $-0.046^{*}$ & $(0.004)$ & $1998 \cdot \mathrm{EE}^{I D}$ & $-0.054^{*}$ & $(0.006)$ \\
\hline 1999 & $0.018^{*}$ & $(0.003)$ & $1999 \cdot \mathrm{EE}^{D}$ & $-0.033^{*}$ & $(0.004)$ & $1999 \cdot \mathrm{EE}^{I D}$ & $-0.014^{*}$ & $(0.006)$ \\
\hline
\end{tabular}

Source: Authors' calculations, based on IABS 1975-2004.

Note: Dependent variable is the log real daily wage. Regression also includes gender, skill level, establishment size and industry. Entry year effects are calculated as deviations from the grand mean wage. *: statistically significant at least at the $5 \%$-level. 
Table 7: IV-Estimation of entry year effects five years after labour market entry

\begin{tabular}{|c|c|c|c|c|c|c|c|c|}
\hline & Coeff. & 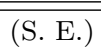 & & Coeff. & 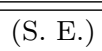 & & Coeff. & (S. E.) \\
\hline Stay & $0.089^{*}$ & $(0.011)$ & $\mathrm{EE}^{D}$ & $0.100^{*}$ & $(0.019)$ & $\mathrm{EE}^{I D}$ & $-0.189^{*}$ & $(0.018)$ \\
\hline 1980 & $-0.076^{*}$ & $(0.003)$ & $1980 \cdot \mathrm{EE}^{D}$ & $0.078^{*}$ & $(0.008)$ & $1980 \cdot \mathrm{EE}^{I D}$ & $0.064^{*}$ & $(0.010)$ \\
\hline 1981 & $-0.095^{*}$ & (0.004) & $1981 \cdot \mathrm{EE}^{D}$ & $0.084^{*}$ & (0.008) & $1981 \cdot \mathrm{EE}^{I D}$ & $0.062^{*}$ & $(0.010)$ \\
\hline 1982 & $-0.102^{*}$ & $(0.004)$ & $1982 \cdot \mathrm{EE}^{D}$ & $0.088^{*}$ & (0.009) & $1982 \cdot \mathrm{EE}^{I D}$ & $0.059^{*}$ & $(0.011)$ \\
\hline 1983 & $-0.083^{*}$ & $(0.004)$ & $1983 \cdot \mathrm{EE}^{D}$ & $0.060^{*}$ & (0.009) & $1983 \cdot \mathrm{EE}^{I D}$ & $0.045^{*}$ & $(0.011)$ \\
\hline 1984 & $-0.058^{*}$ & (0.003) & $1984 \cdot \mathrm{EE}^{D}$ & $0.044^{*}$ & $(0.008)$ & $1984 \cdot \mathrm{EE}^{I D}$ & $0.040^{*}$ & $(0.011)$ \\
\hline 1985 & $-0.056^{*}$ & $(0.003)$ & $1985 \cdot \mathrm{EE}^{D}$ & 0.010 & (0.009) & $1985 \cdot \mathrm{EE}^{I D}$ & $0.028^{*}$ & $(0.011)$ \\
\hline 1986 & $-0.036^{*}$ & (0.003) & $1986 \cdot \mathrm{EE}^{D}$ & $-0.016^{*}$ & (0.008) & $1986 \cdot \mathrm{EE}^{I D}$ & $0.040^{*}$ & $(0.011)$ \\
\hline 1987 & $-0.011^{*}$ & (0.003) & $1987 \cdot \mathrm{EE}^{D}$ & $-0.015^{*}$ & $(0.0$ & $1987 \cdot \mathrm{EE}^{I D}$ & $0.031^{*}$ & $(0.012)$ \\
\hline 1988 & $-0.010^{*}$ & $(0.003)$ & $1988 \cdot \mathrm{EE}^{D}$ & 0.000 & $(0.009)$ & $1988 \cdot \mathrm{EE}^{I D}$ & $0.026 \dagger$ & $(0.012)$ \\
\hline 1989 & 0.003 & $(0.002)$ & $1989 \cdot \mathrm{EE}^{D}$ & 0.004 & $(0.0$ & $1989 \cdot \mathrm{EE}^{I D}$ & 0.019 & $(0.011)$ \\
\hline 1990 & $0.018^{*}$ & $(0.003)$ & $1990 \cdot \mathrm{EE}^{D}$ & -0.007 & $(0.009)$ & $1990 \cdot \mathrm{EE}^{I D}$ & 0.011 & $(0.012)$ \\
\hline 1991 & $0.025^{*}$ & $(0.00$ & $1991 \cdot \mathrm{EE}^{D}$ & $-0.015 \dagger$ & (0. & $1991 \cdot \mathrm{EE}^{I D}$ & 0.008 & $(0.012)$ \\
\hline 1992 & $0.036^{*}$ & $(0.003)$ & $1992 \cdot \mathrm{EE}^{D}$ & $-0.025^{*}$ & $(0.010)$ & $1992 \cdot \mathrm{EE}^{I D}$ & -0.013 & $(0.012)$ \\
\hline 1993 & $0.059^{*}$ & $(0.003)$ & $1993 \cdot \mathrm{EE}^{D}$ & $-0.019 \dagger$ & $(0.011)$ & $1993 \cdot \mathrm{EE}^{I D}$ & $-0.047^{*}$ & $(0.013)$ \\
\hline 1994 & $0.070^{*}$ & $(0.004)$ & $1994 \cdot \mathrm{EE}^{D}$ & $-0.026^{*}$ & $(0.011)$ & $1994 \cdot \mathrm{EE}^{I D}$ & $-0.049 *$ & $(0.014)$ \\
\hline 1995 & $0.082^{*}$ & $(0.004)$ & $1995 \cdot \mathrm{EE}^{D}$ & $-0.035^{*}$ & $(0.011)$ & $1995 \cdot \mathrm{EE}^{I D}$ & $-0.067^{*}$ & $(0.014)$ \\
\hline 1996 & $0.084^{*}$ & $(0.004)$ & $1996 \cdot \mathrm{EE}^{D}$ & $-0.048^{*}$ & $(0.011)$ & $1996 \cdot \mathrm{EE}^{I D}$ & $-0.086^{*}$ & $(0.015)$ \\
\hline 1997 & $0.067^{*}$ & $(0.003)$ & $1997 \cdot \mathrm{EE}^{D}$ & $-0.051^{*}$ & $(0.012)$ & $1997 \cdot \mathrm{EE}^{I D}$ & $-0.078^{*}$ & $(0.014)$ \\
\hline 1998 & $0.043^{*}$ & $(0.003)$ & $1998 \cdot \mathrm{EE}^{D}$ & $-0.050^{*}$ & $(0.011)$ & $1998 \cdot \mathrm{EE}^{I D}$ & $-0.075^{*}$ & $(0.014)$ \\
\hline 1999 & $0.040^{*}$ & $(0.003)$ & $1999 \cdot \mathrm{EE}^{D}$ & $-0.063^{*}$ & $(0.011)$ & $1999 \cdot \mathrm{EE}^{I D}$ & -0.017 & $(0.014)$ \\
\hline
\end{tabular}

Source: Authors' calculations, based on IABS 1975-2004.

Note: See notes to Table 6. *: statistically significant at least at the 5\%-level. $\dagger$ : statistically significant at least at the $10 \%$-level.

Table 8: Estimation of unemployment rate and cohort size on wages

\begin{tabular}{|c|c|c|c|c|c|c|}
\hline & \multicolumn{2}{|c|}{ At entry } & \multicolumn{4}{|c|}{ After 5 years } \\
\hline & Coeff. & (S. E.) & Coeff. & (S. E.) & Coeff. & (S. E.) \\
\hline Unemployment & $-0.01837^{*}$ & $(0.00044)$ & $-0.00557^{*}$ & $(0.00020)$ & $-0.00506^{*}$ & $(0.00052)$ \\
\hline Cohort Size & $-0.00007^{*}$ & $(0.00001)$ & $-0.00002^{*}$ & $(0.00000)$ & $-0.00002^{*}$ & $(0.00000)$ \\
\hline $\mathrm{EE}^{D}$ & & & $0.02519^{*}$ & $(0.00622)$ & & \\
\hline $\mathrm{EE}^{I D}$ & & & 0.01971 & $(0.01484)$ & & \\
\hline Unemployment $\cdot \mathrm{EE}^{D}$ & & & $0.00167^{*}$ & $(0.00032)$ & & \\
\hline Unemployment. $\mathrm{EE}^{I D}$ & & & $0.00241^{*}$ & $(0.00060)$ & & \\
\hline Cohort Size $\cdot \mathrm{EE}^{D}$ & & & 0.00001 & $(0.00001)$ & & \\
\hline Cohort Size $\cdot \mathrm{EE}^{I D}$ & & & $0.00002^{*}$ & $(0.00001)$ & & \\
\hline $\mathrm{EE}^{O S}$ & & & & & $0.03671^{*}$ & $(0.00804)$ \\
\hline $\mathrm{EE}^{O M}$ & & & & & $0.01524^{*}$ & $(0.00796)$ \\
\hline Unemployment $\cdot \mathrm{EE}^{O S}$ & & & & & $0.00099^{*}$ & $(0.00041)$ \\
\hline Unemployment $\cdot \mathrm{EE}^{O M}$ & & & & & $0.00352^{*}$ & $(0.00040)$ \\
\hline Cohort Size $\cdot \mathrm{EE}^{O S}$ & & & & & $0.00002^{*}$ & $(0.00001)$ \\
\hline Cohort Size.EE ${ }^{O M}$ & & & & & $0.00002^{*}$ & $(0.00001)$ \\
\hline
\end{tabular}

Source: Authors' calculations, based on IABS 1975-2004.

Note: Dependent variable is the log real daily wage. Regression also includes gender, skill level, establishment size and industry. *: statistically significant at least at the 5\%-level. 
Figure 1: Wages by year of labour market entry

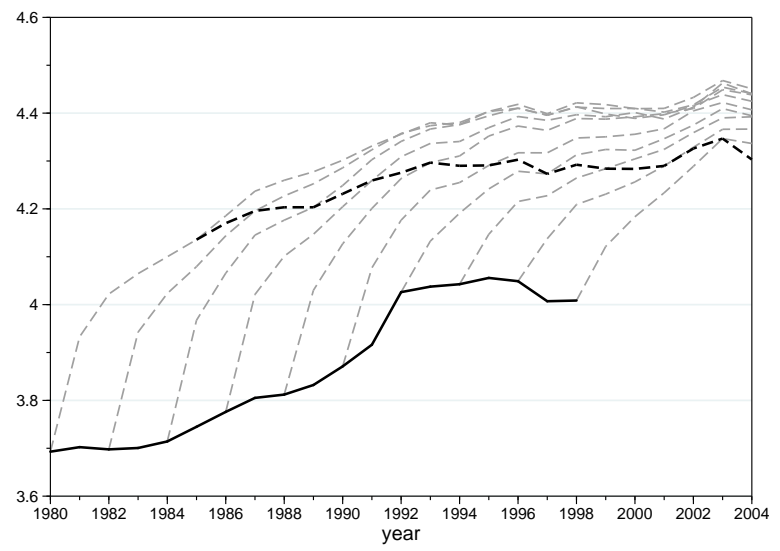

Source: Authors' calculations, based on IABS 1975-2004.

Note: The grey broken lines show the evolution of wages for cohorts entering the labour market between 1980 and 1999. The black solid and the black broken lines show cohort wages at labour market entry and five years after labour market entry, respectively.

Figure 2: Starting wages and GDP growth

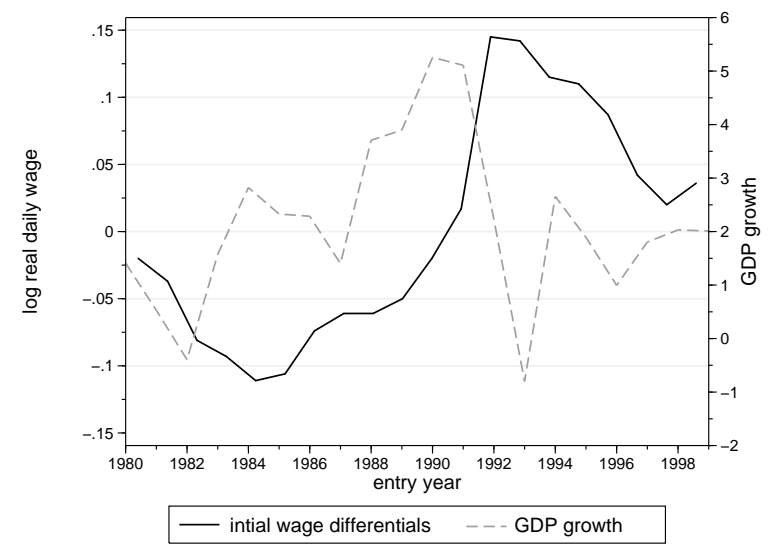

Source: Authors' calculations, based on IABS 1975-2004.

Note: Wages are detrended by using a Hodrick-Prescott (HP) filter. Following Ravn and Uhlig (2002) we apply a HP smoothing parameter value of 6.25 for our yearly data. 
Figure 3: Entry year effects five years after labour market entry

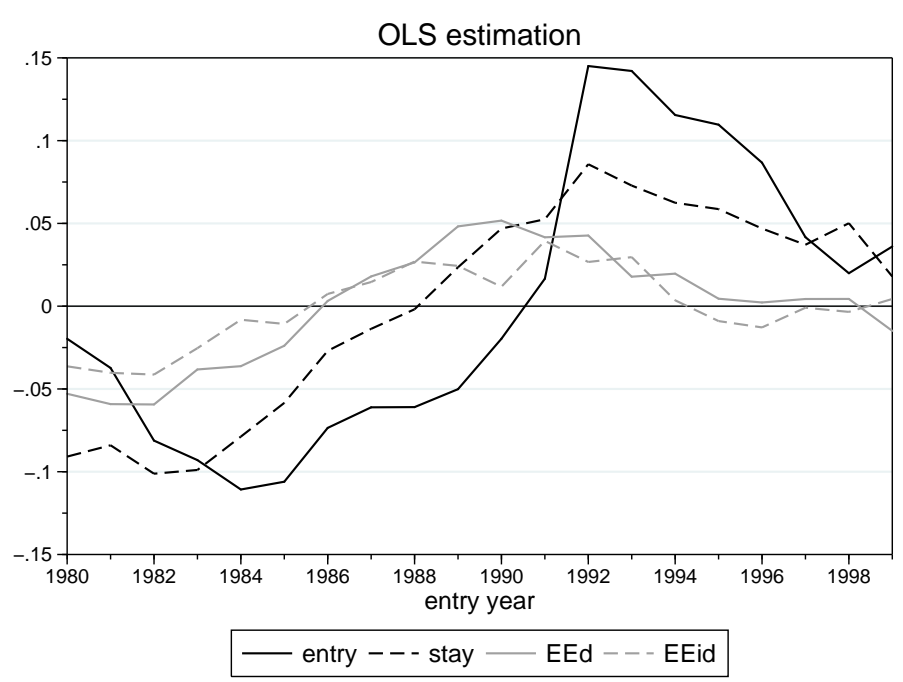

Source: Authors' calculations, based on IABS 1975-2004.

Note: See notes to Table 6.

Figure 4: Entry year effects five years after labour market entry and occupational change

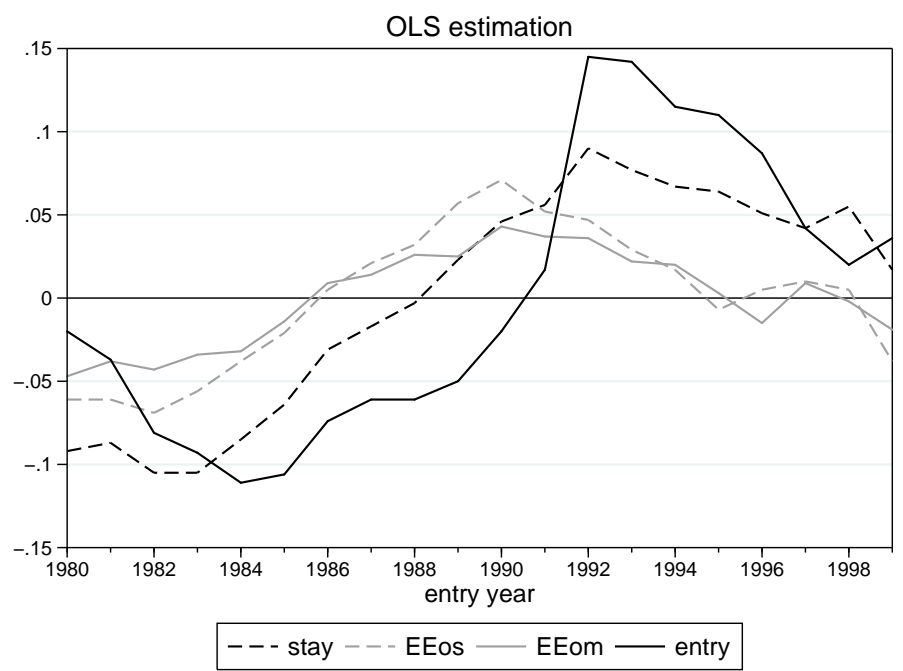

Source: Authors' calculations, based on IABS 1975-2004.

Note: See notes to Table 6. 
Figure 5: Entry year effects five years after labour market entry by skill level
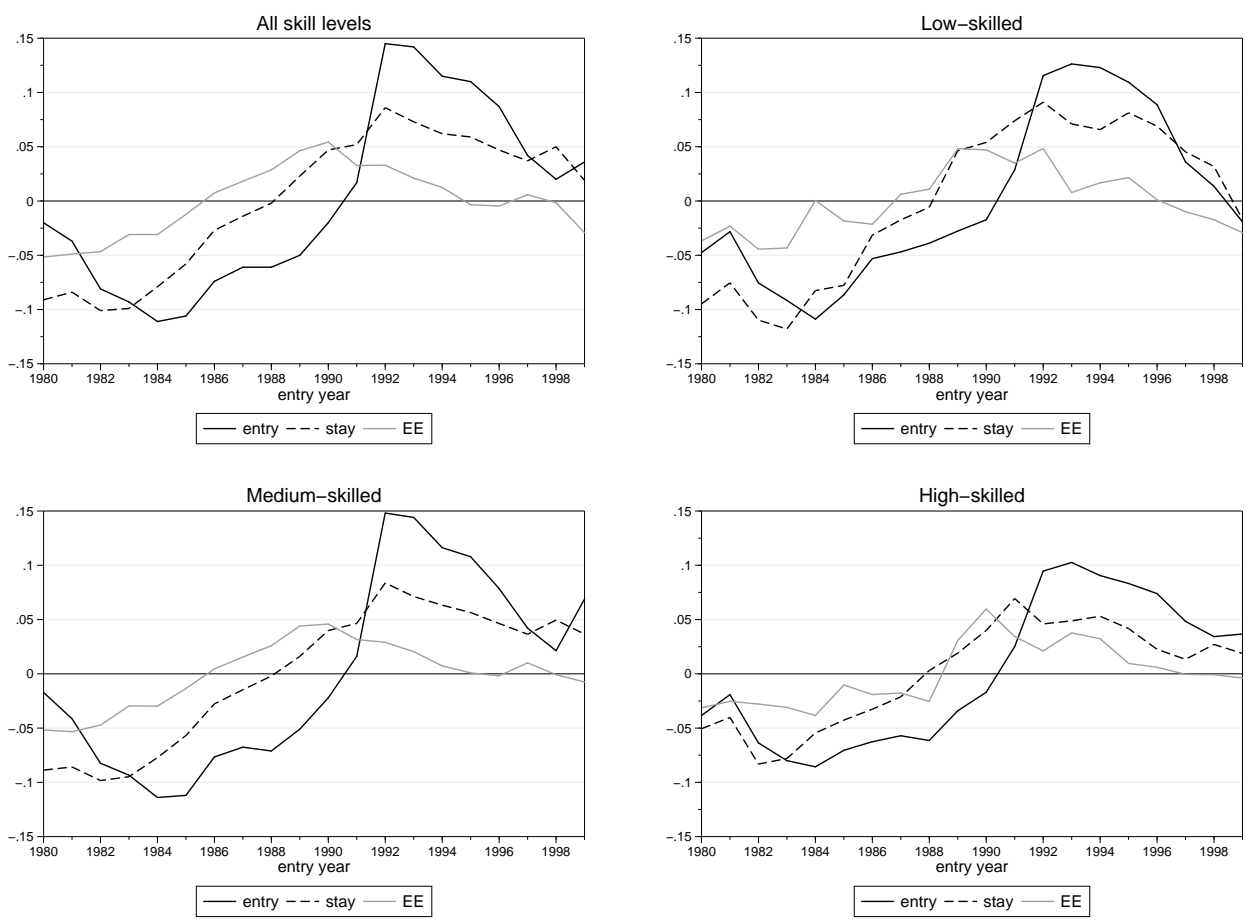

Source: Authors' calculations, based on IABS 1975-2004.

Note: See notes to Table 6.

Figure 6: Estimated entry year effects five years after labour market entry: IV results

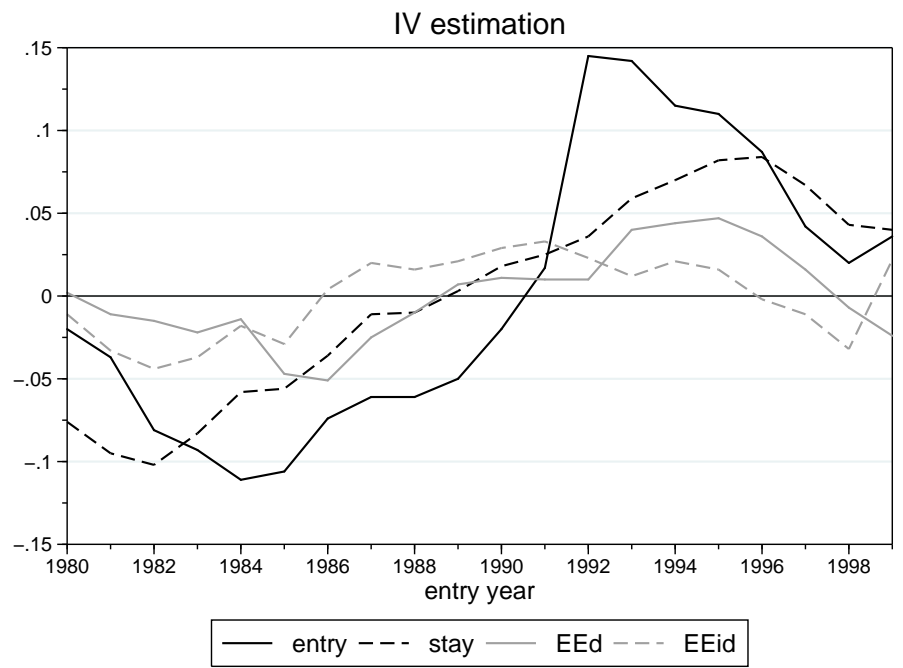

Source: Authors' calculations, based on IABS 1975-2004.

Note: See notes to Table 6. 


\section{Appendix}

Table A.1: Definition of characteristics

\begin{tabular}{|c|c|c|c|}
\hline Variable & Mean & Std. Dev. & Definition \\
\hline EU flows & 0.0645 & 0.2456 & Transitions from employment to unemployment. \\
\hline EN flows & 0.1208 & 0.3252 & Transitions from employment to nonparticipation. \\
\hline $\mathrm{EE}$ & 0.1625 & 0.3807 & Transitions from one employer to another. \\
\hline $\mathrm{EE}^{D}$ flows & 0.1158 & 0.3201 & $\begin{array}{l}\text { Direct EE flows and EE flows with an intervening } \\
\text { nonemployment spell }<1 \text { month. }\end{array}$ \\
\hline $\mathrm{EE}^{I D}$ flows & 0.0467 & 0.2107 & $\begin{array}{l}\text { EE flows with an intervening nonemployment spell } \\
\geq 1 \text { month. }\end{array}$ \\
\hline $\mathrm{EE}^{O S}$ flows & 0.0894 & 0.2951 & 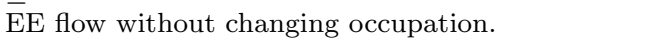 \\
\hline $\mathrm{EE}^{O M}$ flows & 0.0731 & 0.2706 & EE flow with changing occupation. \\
\hline Age & 22.413 & 3.0156 & Age of individual. \\
\hline Low-skilled & 0.1767 & 0.3785 & $\begin{array}{l}\text { Dummy }=1 \text { if individual holds a lower secondary } \\
\text { school diploma without a professional degree. }\end{array}$ \\
\hline Medium-skilled & 0.7601 & 0.4260 & $\begin{array}{l}\text { Dummy }=1 \text { if individual has a lower secondary } \\
\text { school diploma and professional degree; or a high } \\
\text { school diploma and without a professional degree; } \\
\text { or a school diploma as well as a professional de- } \\
\text { gree. }\end{array}$ \\
\hline High-skilled & 0.0632 & 0.2364 & $\begin{array}{l}\text { Dummy }=1 \text { if individual holds a university degree } \\
\text { or university of applied sciences degree. }\end{array}$ \\
\hline \multirow[t]{6}{*}{ Industry dummies } & 0.0225 & 0.1451 & Agriculture, Mining and Energy \\
\hline & 0.2986 & 0.4434 & Production \\
\hline & 0.0918 & 0.2875 & Construction \\
\hline & 0.2624 & 0.4571 & Trade, Transport \\
\hline & 0.2875 & 0.4563 & Services \\
\hline & 0.0372 & 0.1901 & State. \\
\hline \multirow[t]{4}{*}{ Establishment size dummies } & 0.3101 & 0.4580 & 1-19 employees \\
\hline & 0.2539 & 0.4387 & 20-99 employees \\
\hline & 0.2785 & 0.4399 & 100-999 employees \\
\hline & 0.1575 & 0.3931 & more than 1000 employees \\
\hline Entry Wage & 39.725 & 16.368 & Real daily wage at the time of labour market entry. \\
\hline Wage & 55.481 & 24.176 & Real daily wage. \\
\hline Positive wage gap & 0.0667 & 0.0952 & Positive deviation from grand mean starting wage. \\
\hline Negative wage gap & 0.1015 & 0.0983 & $\begin{array}{l}\text { Negative deviation from grand mean starting } \\
\text { wage. }\end{array}$ \\
\hline Unemployment & 7.8923 & 2.6505 & $\begin{array}{l}\text { Federal unemployment rate in the year of labour } \\
\text { market entry (in \%). }\end{array}$ \\
\hline Cohort size & 10073.2 & 1884.1 & $\begin{array}{l}\text { Size of entry cohort in the year of labour market } \\
\text { entry. }\end{array}$ \\
\hline
\end{tabular}

Source: Authors' calculations, based on IABS 1975-2004. 
Table A.2: Cohort characteristics at labour market entry

\begin{tabular}{lcccccc}
\hline \hline Year of & \multicolumn{5}{c}{ Characteristics } \\
\cline { 2 - 7 } entry & Age & Female & Low-skill & Med-skill & High-skill & Cohort size \\
\hline 1980 & $19.76(2.64)$ & $0.46(0.50)$ & $0.28(0.45)$ & $0.68(0.47)$ & $0.04(0.20)$ & $13314(0)$ \\
1981 & $19.72(2.40)$ & $0.45(0.50)$ & $0.25(0.43)$ & $0.71(0.45)$ & $0.04(0.19)$ & $12310(0)$ \\
1982 & $19.92(2.40)$ & $0.45(0.50)$ & $0.21(0.41)$ & $0.75(0.44)$ & $0.04(0.19)$ & $10962(0)$ \\
1983 & $20.06(2.45)$ & $0.46(0.50)$ & $0.20(0.40)$ & $0.75(0.43)$ & $0.04(0.21)$ & $10416(0)$ \\
1984 & $20.14(2.40)$ & $0.45(0.50)$ & $0.20(0.40)$ & $0.75(0.43)$ & $0.04(0.20)$ & $10470(0)$ \\
1985 & $20.40(2.53)$ & $0.46(0.50)$ & $0.19(0.40)$ & $0.75(0.43)$ & $0.05(0.22)$ & $10592(0)$ \\
1986 & $20.56(2.49)$ & $0.46(0.50)$ & $0.17(0.38)$ & $0.78(0.42)$ & $0.05(0.21)$ & $11647(0)$ \\
1987 & $20.75(2.54)$ & $0.47(0.50)$ & $0.17(0.37)$ & $0.78(0.41)$ & $0.05(0.22)$ & $11702(0)$ \\
1988 & $20.91(2.60)$ & $0.46(0.50)$ & $0.17(0.37)$ & $0.78(0.42)$ & $0.05(0.22)$ & $11362(0)$ \\
1989 & $21.02(2.64)$ & $0.46(0.50)$ & $0.17(0.37)$ & $0.77(0.42)$ & $0.06(0.24)$ & $12060(0)$ \\
1990 & $21.14(2.67)$ & $0.47(0.50)$ & $0.16(0.37)$ & $0.77(0.42)$ & $0.06(0.24)$ & $11739(0)$ \\
1991 & $21.39(2.80)$ & $0.48(0.50)$ & $0.16(0.37)$ & $0.77(0.42)$ & $0.07(0.25)$ & $10689(0)$ \\
1992 & $21.67(2.86)$ & $0.49(0.50)$ & $0.15(0.35)$ & $0.78(0.41)$ & $0.07(0.26)$ & $10376(0)$ \\
1993 & $21.63(2.82)$ & $0.48(0.50)$ & $0.13(0.33)$ & $0.80(0.40)$ & $0.07(0.26)$ & $8602(0)$ \\
1994 & $21.65(2.88)$ & $0.47(0.50)$ & $0.14(0.34)$ & $0.78(0.41)$ & $0.08(0.27)$ & $7822(0)$ \\
1995 & $21.72(2.94)$ & $0.44(0.50)$ & $0.15(0.36)$ & $0.76(0.42)$ & $0.08(0.28)$ & $7596(0)$ \\
1996 & $21.69(2.92)$ & $0.47(0.50)$ & $0.14(0.34)$ & $0.78(0.42)$ & $0.08(0.27)$ & $6716(0)$ \\
1997 & $21.78(2.93)$ & $0.46(0.50)$ & $0.15(0.35)$ & $0.77(0.42)$ & $0.08(0.27)$ & $6873(0)$ \\
1998 & $21.87(3.04)$ & $0.47(0.50)$ & $0.16(0.37)$ & $0.74(0.44)$ & $0.09(0.29)$ & $7016(0)$ \\
1999 & $21.68(2.86)$ & $0.45(0.50)$ & $0.17(0.38)$ & $0.75(0.44)$ & $0.08(0.26)$ & $6800(0)$ \\
\hline
\end{tabular}

Source: Authors' calculations, based on IABS 1975-2004.

Table A.3: Distribution of stayers and movers

\begin{tabular}{lccccccc}
\hline \hline & Stay & $\mathrm{EE}$ & $\mathrm{EE}^{D}$ & $\mathrm{EE}^{I D}$ & $\mathrm{EE}^{D+I D}$ & $\mathrm{EE}^{O S}$ & $\mathrm{EE}^{O M}$ \\
\hline 1980 & 0.367 & 0.633 & 0.352 & 0.130 & 0.151 & 0.231 & 0.402 \\
1981 & 0.373 & 0.628 & 0.334 & 0.141 & 0.153 & 0.243 & 0.385 \\
1982 & 0.385 & 0.615 & 0.332 & 0.138 & 0.145 & 0.245 & 0.370 \\
1983 & 0.398 & 0.602 & 0.323 & 0.134 & 0.145 & 0.245 & 0.357 \\
1984 & 0.401 & 0.599 & 0.344 & 0.113 & 0.142 & 0.238 & 0.361 \\
1985 & 0.410 & 0.591 & 0.353 & 0.101 & 0.137 & 0.233 & 0.358 \\
1986 & 0.423 & 0.578 & 0.352 & 0.087 & 0.139 & 0.243 & 0.335 \\
1987 & 0.430 & 0.570 & 0.355 & 0.086 & 0.129 & 0.248 & 0.322 \\
1988 & 0.446 & 0.555 & 0.356 & 0.077 & 0.122 & 0.234 & 0.321 \\
1989 & 0.448 & 0.552 & 0.356 & 0.072 & 0.124 & 0.233 & 0.319 \\
1990 & 0.429 & 0.571 & 0.374 & 0.071 & 0.126 & 0.250 & 0.321 \\
1991 & 0.439 & 0.561 & 0.353 & 0.092 & 0.116 & 0.248 & 0.313 \\
1992 & 0.437 & 0.562 & 0.349 & 0.094 & 0.119 & 0.274 & 0.288 \\
1993 & 0.425 & 0.576 & 0.345 & 0.101 & 0.130 & 0.271 & 0.305 \\
1994 & 0.428 & 0.573 & 0.347 & 0.097 & 0.129 & 0.264 & 0.309 \\
1995 & 0.436 & 0.564 & 0.333 & 0.102 & 0.129 & 0.244 & 0.320 \\
1996 & 0.440 & 0.561 & 0.330 & 0.098 & 0.133 & 0.259 & 0.302 \\
1997 & 0.431 & 0.570 & 0.348 & 0.095 & 0.127 & 0.246 & 0.324 \\
1998 & 0.457 & 0.544 & 0.325 & 0.096 & 0.123 & 0.244 & 0.300 \\
1999 & 0.429 & 0.571 & 0.362 & 0.092 & 0.117 & 0.256 & 0.315 \\
\hline
\end{tabular}

Source: Authors' calculations, based on IABS 1975-2004.

Note: The flow definitions are in Table A.1. 